\title{
Vegetation history and paleoclimate at Lake Dojran (FYROM/Greece) during the Late Glacial and Holocene
}

\author{
Alessia Masi ${ }^{1}$, Alexander Francke ${ }^{2,3}$, Caterina Pepe ${ }^{1}$, Matthias Thienemann ${ }^{2}$, Bernd Wagner ${ }^{2}$, and Laura Sadori ${ }^{1}$ \\ ${ }^{1}$ Department of Environmental Biology, Sapienza University, Rome, Italy \\ ${ }^{2}$ Institute of Geology and Mineralogy, University of Cologne, Cologne, Germany \\ ${ }^{3}$ Wollongong Isotope Geochronology Laboratory, School of Earth and Environmental Sciences, University of Wollongong, \\ Wollongong, Australia
}

Correspondence: Alessia Masi (alessia.masi@uniroma1.it)

Received: 10 September 2017 - Discussion started: 29 September 2017

Revised: 8 February 2018 - Accepted: 12 February 2018 - Published: 13 March 2018

\begin{abstract}
A new high-resolution pollen and NPP (nonpollen palynomorph) analysis has been performed on the sediments of Lake Dojran, a transboundary lake located at the border between Greece and the former Yugoslav Republic of Macedonia (FYROM). The sequence covers the last 12500 years and provides information on the vegetational dynamics of the Late Glacial and Holocene for the southern Balkans. Robust age model, sedimentological diatom, and biomarker analyses published previously have been the base for a multi-perspective interpretation of the new palynological data. Pollen analysis revealed that the Late Glacial is characterized by steppic taxa with prevailing Amaranthaceae, Artemisia and Poaceae. The arboreal vegetation starts to rise after $11500 \mathrm{yr} \mathrm{BP}$, taking a couple of millennia to be definitively attested. Holocene vegetation is characterized by the dominance of mesophilous plants. The Quercus robur type and Pinus are the most abundant taxa, followed by the Quercus cerris type, the Quercus ilex type and Ostrya-Carpinus orientalis. The first attestation of human presence can be presumed at $5000 \mathrm{yr}$ BP from the contemporary presence of cereals, Juglans and Rumex. A drop in both pollen concentration and influx together with a $\delta^{18} \mathrm{O}_{\text {carb }}$ shift indicates increasing aridity and precedes clear and continuous human signs since $4000 \mathrm{yr}$ BP. Also, a correlation between Pediastrum boryanum and fecal stanol suggests that the increase in nutrients in the water is related to human presence and pasture. An undoubted expansion of humanrelated plants occurs since $2600 \mathrm{yr}$ BP when cereals, arboreal cultivated and other synanthropic non-cultivated taxa are found. A strong reduction in arboreal vegetation occurred at
\end{abstract}

2000 yr BP, when the Roman Empire impacted a landscape undergoing climate dryness in the whole Mediterranean area. In recent centuries the human impact still remains high but spots of natural vegetation are preserved. The Lake Dojran multi-proxy analysis including pollen data provides clear evidence of the importance of this approach in paleoenvironmental reconstruction. Cross-interpretation of several proxies allows us to comprehend past vegetation dynamics and human impact in the southern Balkans.

\section{Introduction}

High-resolution terrestrial archives from lakes and caves are the basis for understanding past climate changes and vegetation dynamics. Southern Europe counts a large number of extant lakes and paleo-lakes in comparison to northern African and Near Eastern regions. This is due to the geological features, geographical location and related hydrological and climatic conditions that characterize the southernmost European countries.

While a lot of Spanish, French, Italian and Greek lacustrine records have been studied since the 1970s, the vegetation dynamics of the central Balkans remained for a long time under-investigated due to a variety of natural, historical and political circumstances. Nevertheless, there are two remarkable reasons that make the area important for paleoenvironmental investigation: (1) the possibility to obtain long lacustrine records due to the high abundance of tectonic lakes, such as Dojran, Prespa, Ohrid and Maliq and (2) the 
long-lasting human occupation. Only recently has the scientific community appreciated all the potentialities of the area, which is quite rich in natural lakes, and a number of international teams are currently carrying out interdisciplinary investigations in the area. This massive boost involved either the totally new or the renewed study of several long Quaternary lacustrine sediment records: Ioannina basin (Tzedakis, 1994; Lawson et al., 2004; Roucoux et al., 2011), Lake Ohrid (Wagner et al., 2009, 2017; Lézine et al., 2010; Sadori et al., 2016b), Lake Prespa (Panagiotopoulos et al., 2014) and Tenaghi Philippon (e.g., Tzedakis et al., 2006; Milner et al., 2012; Pross et al., 2015).

The area in general and the central-western Balkan lakes in particular (Butrint, Dojran, Ohrid, Prespa and Shkodra) are characterized by pristine nature and are important hotspots of biodiversity for aquatic and wetland life, but also for terrestrial plants and animals (Griffiths et al., 2002; Keukelaar et al., 2006; Bojovic et al., 2016). Since the publication of the paper by Willis (1994) on Balkan vegetation history, new data have become available. In particular, investigations of Holocene changes in the last 20 years concerned two lagoons from the island of Mljet (Jahns and van den Bogaard, 1998), Lake Shkodra (Zanchetta et al., 2012; Sadori et al., 2015a; Mazzini et al., 2016), Lake Butrint (Morellon et al., 2016), Lake Orestiás (Kouli, 2015; Kouli and Dermitzakis, 2010), Lake Voulkaria (Jahns, 2005), several Bulgarian mountain lakes (Tonkov and Marinova, 2005; Tonkov et al., 2008, 2016), the peat bog Vodniza (Tonkov et al., 2018) and Lake Dojran (Athanasiadis et al., 2000).

Athanasiadis et al. (2000) provided pollen results for littoral cores from Lake Dojran covering about the last 5000 years. The lacustrine record appeared to be an important archive of past environmental history and climate change of the region. The high potentiality of the archive appeared even clearer in a new longer record from the central part of the lake. This core spans the Late Glacial and the Holocene and provides a multidisciplinary dataset including geochemical (Francke et al., 2013a), diatom (Zhang et al., 2014) and biomarker (Thienemann et al., 2017) data. The new palynological study on Lake Dojran presented here represents the first detailed and continuous Holocene pollen sequence for the region based on a robust chronology and aims at (1) a high-resolution reconstruction of vegetation dynamics of Lake Dojran, (2) an evaluation of the ecosystem response to the transition from the dry-cold climate of the last glacial to the wet-hot climate of the Holocene interglacial (3), an assessment of the human impact and (4) comparison with nearby sequences in order to infer vegetation and humaninduced similarities and dissimilarities.

\section{Site, climate and modern vegetation description}

Lake Dojran $\left(41^{\circ} 12^{\prime} \mathrm{N}, 22^{\circ} 44^{\prime} \mathrm{E}\right)$ is a transboundary lake situated at the border between the former Yugoslav Repub- lic of Macedonia (FYROM) and Greece. The lake is located at $144 \mathrm{~m}$ above sea level (a.s.1.) in a karst depression between two mountain chains: Belles or Belasitsa (peaking at $1870 \mathrm{~m}$ a.s.1.) in the northeast and Krousia or Krusa (860 m a.s.1.) in the southeast (Sotiria and Petkovski, 2004). Lake Dojran is a relict of the former Pleistocene Lake Peon, which occupied an area of about $127 \mathrm{~km}^{2}$ (Petkovski et al., 2004). The lake has an elliptic shape with a maximum northsouth extension of $9 \mathrm{~km}$ and a maximum east-west extension of $7 \mathrm{~km}$. With its $43 \mathrm{~km}^{2}$ of surface, it is one of the smallest lakes in the region. Small rivers, creeks and groundwaters feed the lake. The outlet is an artificial channel, the Doiranitis River, which drains into the Axios River. The outlet is active only when the lake water level is high. It depends on rainfall, summer evaporation and in recent years on the use of water for irrigation (Griffiths et al., 2002; Sotiria and Petkovski, 2004). The result of overexploitation during the last decades of the past century was a drastic water level drop (water depth reached $4 \mathrm{~m}$ in 2001-2002; Sotiria and Petkovski, 2004). To restore the water depth at about $10 \mathrm{~m}$ as it was during the 1950 s, water from nearby aquifers is pumped into the lake (Bojovic et al., 2016).

The regional climate is mainly influenced by the Mediterranean Sea, separated from the lake by the Thessaloniki Plain. The proximity to the sea and the local morphology mitigate the climate that is warmer than in other Macedonian areas (Sotiria and Petkovski, 2004; Popovska et al., 2014). For the period 1961-2000, the mean annual air temperature and precipitation were $14.3{ }^{\circ} \mathrm{C}$ and $612 \mathrm{~mm}$, respectively. Precipitation occurs mainly during the mild winters, when mean temperatures of $3.7^{\circ} \mathrm{C}$ are recorded. Summers are dry, with mean temperatures of $26.1^{\circ} \mathrm{C}$ (Sotiria and Petkovski, 2004).

The modern vegetation of the Balkans is the result of the combined effects of climate, altitude, soil, Mediterranean Sea influence and anthropogenic activity. Mediterranean, Northern and Eastern European floral elements compose the high biodiversity of the area that is also evidenced by a high endemism (Bojovic et al., 2016). The relative proximity to the Aegean Sea $(70 \mathrm{~km})$ also influences the vegetation, resulting in the presence of Mediterranean taxa. The Mediterranean plant communities are characterized by evergreen forests dominated by Pinus halepensis Mill., evergreen Quercus (Quercus coccifera L., Quercus ilex L.) and Juniperus oxycedrus L., while deciduous forest includes Quercus pubescens Willd., Carpinus orientalis Mill., Ostrya carpinifolia Scop., Pistacia terebinthus L., Fraxinus ornus L. and Acer. Montane forests cover the mountain chains between 700 and $1700 \mathrm{~m}$ a.s.l. with Abies and Juniperus. Above $1700 \mathrm{~m}$, subalpine and alpine vegetation prevails (Eastwood, 2004).

In the Dojran catchment, plant associations in which montane, mesophilous and Mediterranean are either organized into vegetation belts or mixed are CocciferoCarpinetum orientalis, Carpinetum orientalis, Quercetum confertae-cerris, Orno-Quercetum petraeae, Fagetum submontanum, Juglando-Platanetum orientalis, Carpine- 
tum orientalis-Quercetum coccifera, Carpinetum orientalisPhilyrietosum mediae, Carpinetum orientalis-Quercetosum confertae and Carpinetum orientalis-Quercetum sessiliflorae (Sotiria and Petkovski, 2004). Sotiria and Petkovski (2004) also list riparian forests dominated by Salix alba and Populus alba galleries. Athanasiadis et al. (2000) report for the vegetation surrounding Lake Dojran the presence of mesophilous forests mainly composed of Quercus pedunculiflora C. Koch., Fraxinus oxycarpa Willd., Alnus glutinosa (L.) Gaertn., Ulmus minor Mill., Ulmus laevis Pall., Platanus orientalis L., Vitis sylvestris Gmel., Humulus lupulus L. and Periploca graeca L. Evergreen oaks are mainly represented by Quercus coccifera L. The lake and part of its surroundings are considered important areas of biodiversity and included in the IPAs (important plant areas) list (Melovski et al., 2012). Vegetation near shores is typical for pseudomaquis and consists of Quercus coccifera L., Quercus pubescens Willd., Carpinus orientalis Mill., Clematis flammula L., Juniperus oxycedrus L., Pistacia terebinthus L., Ulmus minor Mill., Ficus carica L. and Rhamnus saxatilis subsp. rodopea (Velen.) Aldén (Rhamnus rhodopea; http://plantlifeipa.org/Factsheet.asp?sid=1495, Čarni et al., 2003).

Extensive reed beds surround the lake shore. Phragmites australis (Cav.) Steud., Schoenoplectus lacustris (L.) Palla (Scirpus lacustris L.), Typha angusifolia L., Typha latifolia L., Sparganium neglectum and Sparganium erectum aggr. are the most common taxa. When the water level decreases the wet soil becomes a green carpet of the grass Paspalum distichum ssp. paspalodes (Michx.) Thell. (Athanasiadis et al., 2000; Sotiria and Petkovski, 2004; Bojovic et al., 2016). Today, anthropogenic activity including the cultivation of grapes, vegetables, cereals, tobacco and forage crops seriously disturbs the vegetation surrounding the lake (Bojovic et al., 2016).

\section{Material and methods}

\subsection{Coring, chronology and sedimentological analysis}

A $717 \mathrm{~cm}$ long sediment sequence (Co1260) was recovered by a gravity corer and percussion piston corer in June 2011 from the Macedonian part of the lake (Fig. 1), where a hydroacoustic survey (Innomar SES-2000 compact; $10 \mathrm{kHz}$ ) indicated undisturbed, horizontal bedded sediments (Francke et al., 2013a). The age model is based on 13 calibrated radiocarbon ages derived from terrestrial plant material, charcoal, carbonates and bulk organic $\mathrm{C}$ samples (Francke et al., 2013a). The sediment sequence encompasses the last $\sim 12500$ years, i.e., the Late Glacial and the entire Holocene. Sedimentological, stable isotope (Francke et al., 2013a), diatom (Zhang et al., 2014) and biomarker (Thienemann et al., 2017) data provide a robust basis for a new study of pollen on the sequence.
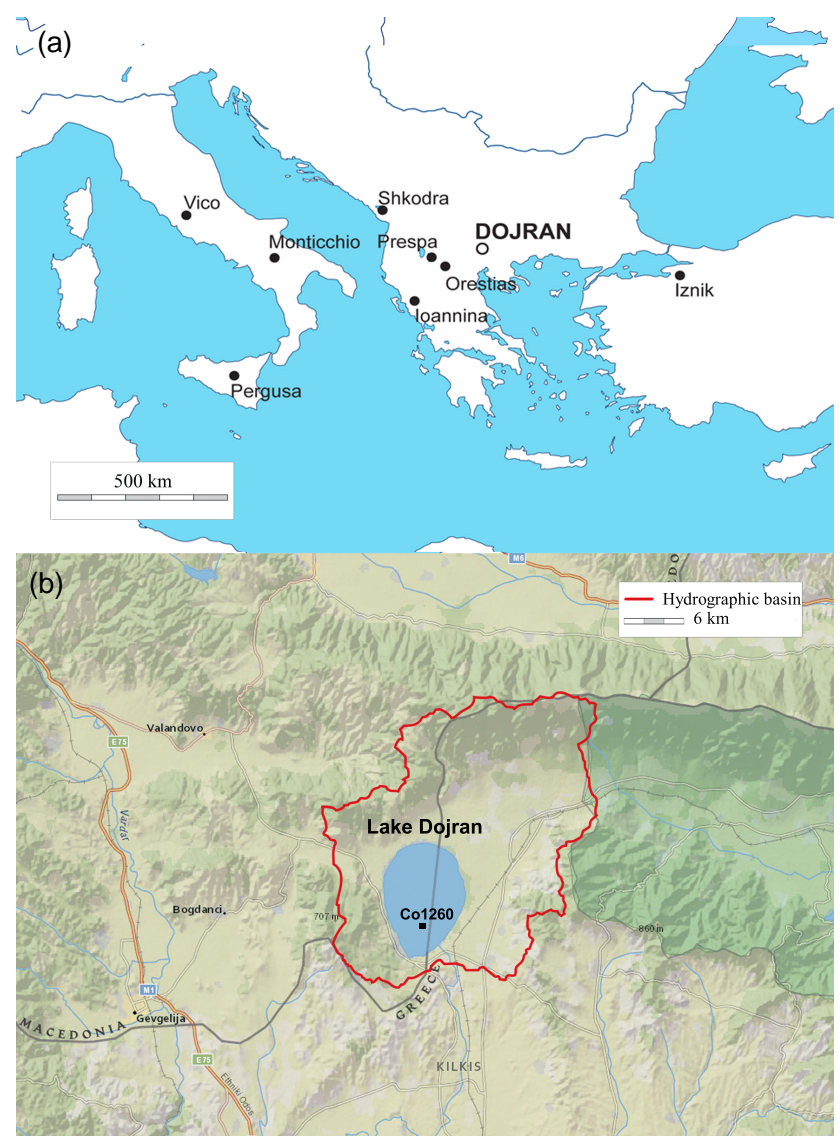

Figure 1. (a) Location of Lake Dojran and the other sites mentioned in the paper. (b) Detail of the lake and its surrounding, the hydrological basin and the location of the analyzed core Co1260. The map is taken from Basemap Esri (https://www.esri.com/en-us/home, last access: 8 March 2018).

\subsection{Pollen analysis}

Palynology has been carried out on 146 sediment samples taken from throughout core Co1260. The mean temporal resolution is 87 years. Between ca. 12500 and $11400 \mathrm{yr} \mathrm{BP}$, the mean temporal resolution is 71 years, and from ca. $3250 \mathrm{yr} \mathrm{BP}$ to $2004 \mathrm{AD}$ it is 66 years. For each sample, 0.29 to $0.57 \mathrm{~g}$ of dry sediment was chemically processed with alternating treatment of $\mathrm{HCl}(37 \%), \mathrm{HF}(40 \%)$ and hot $\mathrm{NaOH}$ (10\%; Fægri and Iversen, 1989, modified) in order to remove detrital matter from the sediments. Following Stockmarr (1971), tablets containing a known amount of Lycopodium spores were added in order to estimate pollen, NPPs (non-pollen palynomorphs) and microcharcoal concentrations. Pollen concentration has been used to elaborate influx data on the basis of the sedimentation rates as inferred from the existing age model. Pollen and microcharcoal influx data are an estimation of the amount of pollen grains and charcoal fragments deposited and incorporated annually in a single unit surface (Berglund et al., 1986). The first is 
an estimate of the plant biomass and the second of the burnt biomass.

The pollen basis sum is constituted by terrestrial spermatophytes. For other taxa, percentages were calculated on different pollen basis sums as reported by Berglund et al. (1986). The identification of pollen morphology is based on atlases (Reille, 1992, 1995, 1998) and reference pollen collections. Pollen diagrams were drawn against both depth and timescales using the TILIA program (Grimm, 1992). All arboreal and non-arboreal pollen taxa with values higher than $2 \%$ of the total pollen sum were used for the CONISS cluster analysis (Grimm, 1992). Pollen zones have been established following CONISS indication and visual inspection.

Pollen grains of several species belonging to genus Quercus have been divided in three morphological groups according to Smit (1973): the Quercus robur type, which includes all deciduous oaks; the Quercus cerris type, which includes all semi-evergreen oaks plus Quercus suber; and the Quercus ilex type, including all the evergreen oaks minus Quercus suber. The denomination Quercus ilex type was kept even if Quercus coccifera is the most common evergreen oak in the area. Among Poaceae, cereals have been identified and mainly include grains ascribable to the Hordeum group and Secale cereale (Andersen et al., 1979). Triticum-Avena pollen grains are present as well. Here, we present a cumulative curve for cereals. The cereal type also includes pollen grains of some wild Poaceae. Considering Asteraceae, pollen grains belonging to the two subfamilies Asteroideae and $\mathrm{Ci}$ chorioideae have been identified. As the tribe Cichorieae, a European native, is the only one with fenestrate pollen grains (Florenzano et al., 2015), Cichorieae would be the most appropriate name instead of Cichorioideae. We keep the more generic name, as it could be more clear for the reader. Among algae, species of Pediastrum, $P$. simplex, $P$. simplex var. sturmii and $P$. boryanum have been recognized following Komárek and Jankovská (2001). Charcoals have been divided into three dimensional groups according to the length of the shorter axis. The particle size reveals the origin of charred fragments: the $10-50 \mu \mathrm{m}$ group indicates regional fire, the 50-125 $\mu \mathrm{m}$ group landscape or regional fire and the $>125 \mu \mathrm{m}$ group local fire (Whitlock et al., 2010; Sadori et al., 2015b).

\section{Results}

The pollen concentration spans from ca. 11200 to

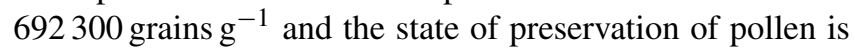
variable. The mean count of terrestrial pollen is 409 grains per sample. A total of 83 terrestrial pollen taxa are identified and include 37 trees and shrubs and 46 herb taxa. The most abundant taxa are the Quercus robur type, Pinus, the Quercus cerris type, the Quercus ilex type and Ostrya-Carpinus orientalis among arboreal plants, with Amaranthaceae, Poaceae and Artemisia among the herbs. CONISS and the results of the pollen analyses, plotted as percentage, concentration and influx values, are shown in Figs. 2 and 3. In Fig. 4, ecological groups (mesophilous, xeric, pioneer, Mediterranean, montane and synanthropic), geochemical proxies, biomarkers and planktonic diatom curves are plotted and diatom zone descriptions are summarized and simplified (for major details and a more precise description, see the paper by Zhang et al., 2014). Amaranthaceae are included in the sum of xeric taxa, even if, especially in the last millennia, some of them can be also an indication of human disturbance. Pollen zones are described also taking into consideration sedimentological and stable isotope data (Francke et al., 2013a), diatom data (Zhang et al., 2014) and biomarker analyses (Thienemann et al., 2017).

\subsection{Pollen zone D-1 (716-599 cm, 12500-11550 yr BP, duration 950 years)}

AP $\%$ ranges from 8 to $38 \%$. Total pollen concentration (pollen grains $\mathrm{g}^{-1}$ ) varies between ca. 11200 and 52600 , influx values between ca. 7200 and 14700 and the number of taxa between 14 and 36. The zone is dominated by herbs. Amaranthaceae are overwhelming along the entire zone (28-70\%; see also concentration and influx values in Fig. 3) and peak at $12000 \mathrm{yr}$ BP (Fig. 2). At the bottom of the record (12500 yr BP), Artemisia has its highest values $(25-32 \%)$, followed by increasing Poaceae that overtake with $30 \%$ at around $11900 \mathrm{yr}$ BP. The presence of 26 arboreal taxa, mainly mesophilous and pioneer ones, is noteworthy. The latter (max. 6\%) are composed of Ephedra (0$3 \%)$, Juniperus (0-2\%), Corylus (0-2\%), Rosaceae undiff. $(0-2 \%)$ and Betula (0-1\%). Pinus pollen shows low values, with two exceptions at $12400(10 \%$ complete and $14 \%$ of broken grains) and 12300 (6\% complete and $16 \%$ of broken grains) yr BP. The Quercus robur type (0-14\%) shows a slight expansion around $12300 \mathrm{yr}$ BP together with a peak of Alnus (5\%). A gradual change in herb vegetation, consisting of a decrease in Artemisia and an increase in Amaranthaceae and Poaceae, is found after $12300 \mathrm{yr}$ BP. This change matches a low lake level as inferred from hydroacoustic data and an increase in salinity indicated by diatoms. Algae (mainly Pediastrum boryanum), aquatic (Myriophyllum) and riparian (Typha angustifolia) plants indicate lacustrine conditions. The sediment features indicate cold and dry conditions until $12100 \mathrm{yr}$ BP. The charcoal presence attests local and regional fires since $12000 \mathrm{yr}$ BP. NPP fungal remains (Glomus and ascospores) increase since $11900 \mathrm{yr} \mathrm{BP}$. Although there are clay clasts that may have formed under subaerial conditions and thus indicate redeposition of sediments in the lowermost core section (Francke et al., 2013a), the pollen assemblage shows the herb vegetation succession typical of the Late Glacial period. 


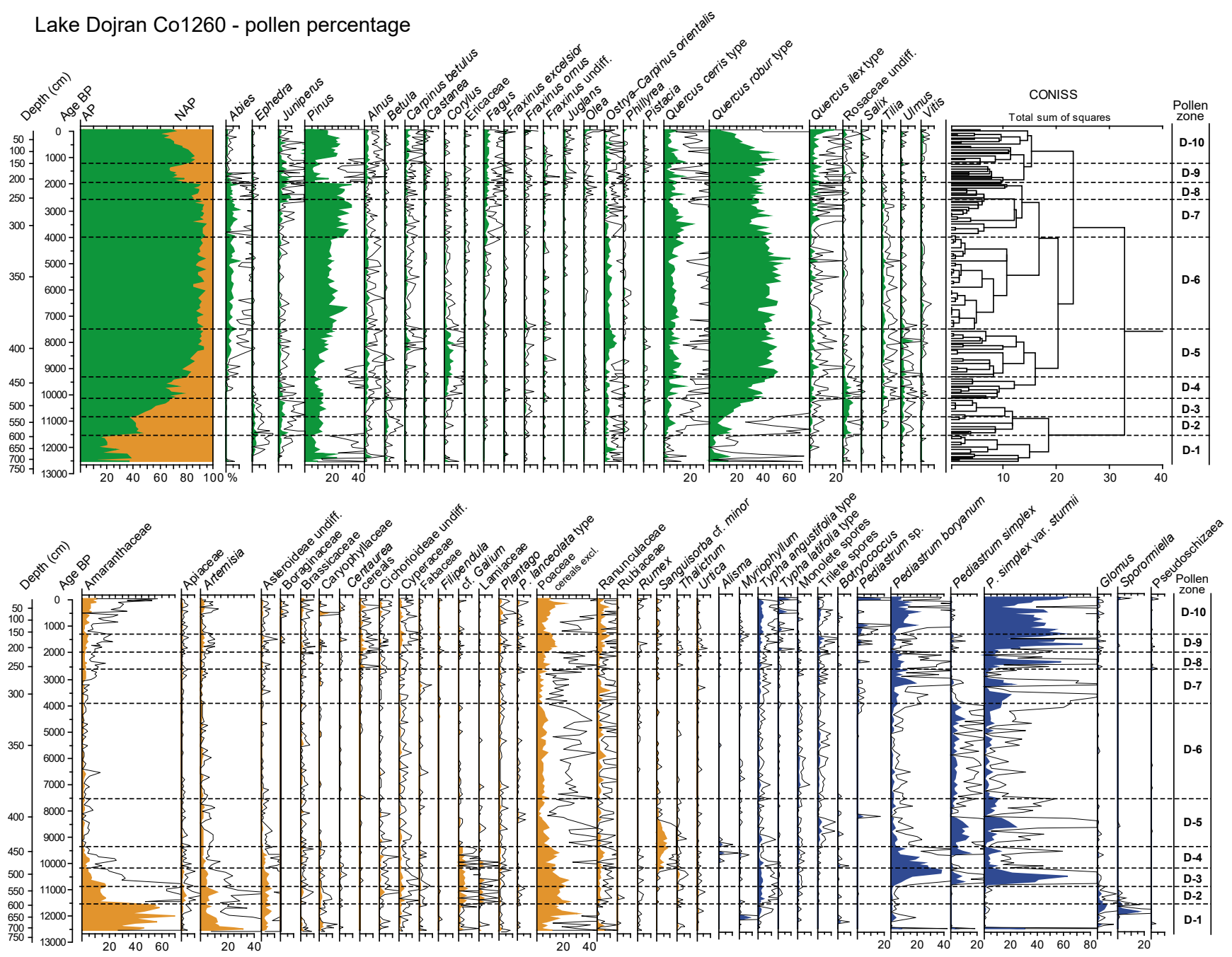

Figure 2. Pollen percentage diagrams of arboreal, non-arboreal and NPP selected taxa and CONISS. Curve magnification $5 \times$.

\subsection{Pollen zone D-2 (593-541 cm, 11500-10 950 yr BP, duration 550 years)}

AP \% ranges from 31 to $45 \%$. Total pollen concentration (pollen grains $\mathrm{g}^{-1}$ ) varies between ca. 25100 and 53200 , influx values between ca. 2600 and 5300 and the number of taxa between 34 and 38. This phase represents the onset of Holocene reforestation. The passage is abrupt and marked by trees increasing from $17 \%$ of D-1 to $31 \%$ of the first sample of D-2. Herbs still prevail and arboreal vegetation is always under $45 \%$. Pioneer taxa (Fig. 4) play a role more important than in the previous zone, with Ephedra $(>0-4 \%)$ slightly decreasing, while Juniperus (1-6\%), Rosaceae undiff. (1$6 \%)$ and Betula (1-3\%) increase. The Quercus robur type (5-16\%) and the Quercus cerris type (2-9\%) dominate among mesophilous taxa with a low contribution of other taxa like Ostrya-Carpinus orientalis (1-3\%) and Ulmus (1$2 \%)$. Mediterranean vegetation is mainly represented by the Quercus ilex type (1-2\%). Poaceae (17-25\%) increase and
Amaranthaceae (10-30\%) highly decrease. Artemisia (3$12 \%)$ and Asteroideae undiff. (2-8\%) are still abundant. Galium (0-6\%) and Lamiaceae $(0-4 \%)$ show the highest values in this zone. Pollen assemblage and $\delta^{18} \mathrm{O}_{\text {carb }}$ values indicate increasing precipitation. Low winter temperatures are inferred by the sporadic occurrence of sand lenses. Low TOC and the abundance of planktonic oligotrophicmesotrophic diatoms indicate low productivity. Charcoal indicates sporadic local and low regional fires. Poaceae, the Typha angustifolia type (2-4\%) and Cyperaceae (0-4\%) could have formed riparian vegetation belts along Lake Dojran shores. This vegetation could have trapped clastic matter and nutrients, explaining the limited productivity of the lake as registered by the sedimentological investigation and by the oligotrophic to mesotrophic water state as inferred from diatom analyses. 
(a) Lake Dojran Co1260 - pollen concentration

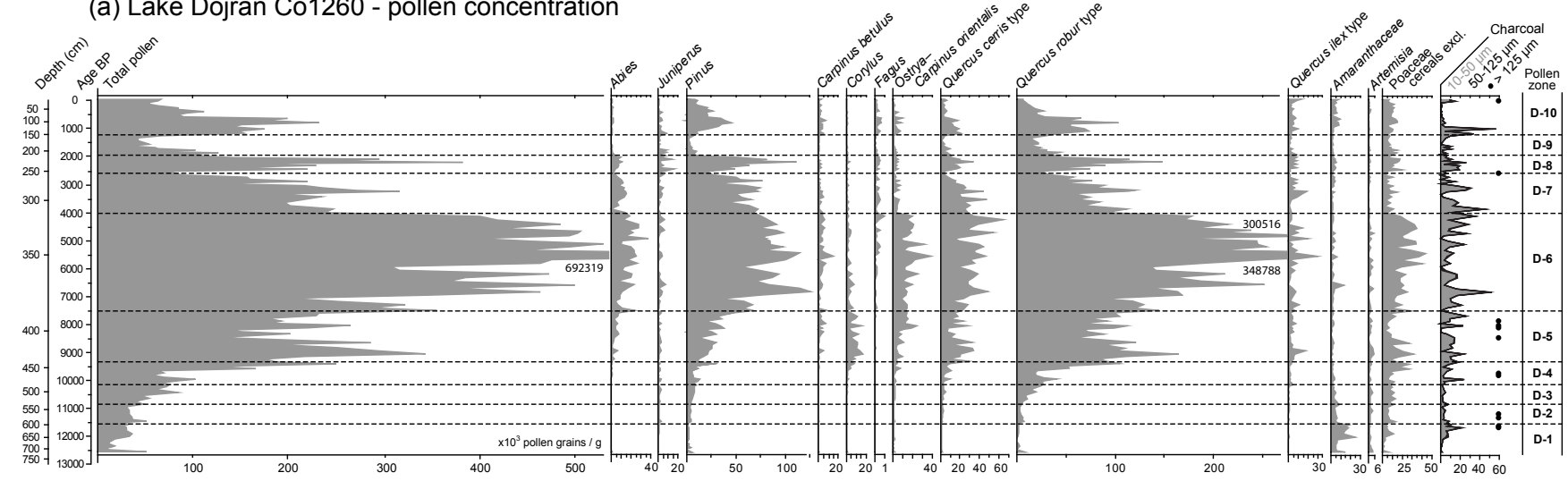

(b) Pollen influx

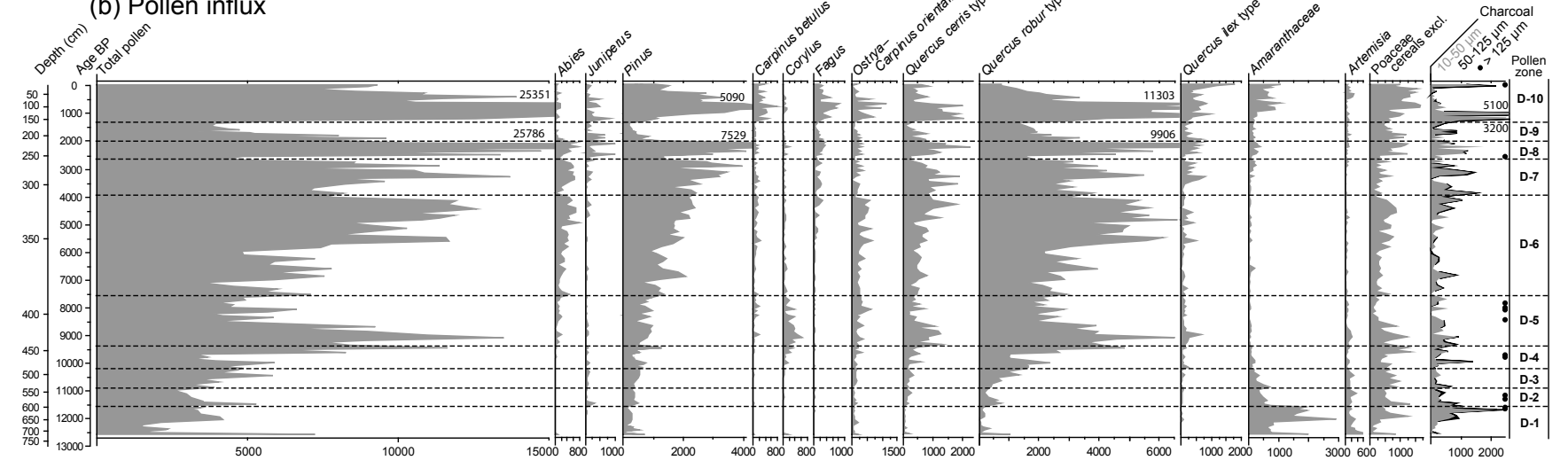

Figure 3. Concentration (a) and influx (b) pollen diagrams of selected taxa and charcoals.

\subsection{Pollen zone D-3 (533-487 cm, 10 850-10 $100 \mathrm{yr} \mathrm{BP,}$ duration 750 years)}

AP \% ranges from 36 to $67 \%$. Total pollen concentration (pollen grains $\mathrm{g}^{-1}$ ) varies between ca. 39500 and 84300 , influx values between ca. 3100 and 5900 and the number of taxa between 35 and 52. Several strong and rapid changes in vegetation are registered in this zone. Arboreal vegetation rises rapidly and woodland is dominated by the Quercus robur type (10-32\%). None of the other mesophilous plants show significant amounts. The only other taxon that shows a considerable presence is Pinus (9-15\%). Pioneer taxa still have very high values. They are mainly Rosaceae undiff. (3$8 \%)$. Among the herbs, Artemisia (2-5\%) and Asteroideae undiff. (3-6\%) are still present together with Amaranthaceae (4-18\%) and Galium (2-5\%). Poaceae (14-22\%) decline even if still showing high percentage and influx values. The increase in water availability is evidenced not only by the rapid increase in mesophilous taxa and the strong reduction of xeric taxa (from 23 to $7 \%$ ), but also by the strong expansion of Pediastrum simplex ( $>0-10 \%)$, Pediastrum simplex var. sturmii (3-63\%), Pediastrum boryanum (3-38\%; Komárek and Jankovská, 2001) and by high values of diatom planktonic taxa. At around $10400 \mathrm{yr}$ BP an important change occurred in all algae. Pediastrum boryanum increases (up to
$38 \%$ ) and facultative planktonic diatoms strongly increase both in percentage (up to ca. $60 \%$ ) and in concentration. Both could therefore either indicate the presence of more nutrients or shallowing water. As vegetation suggests increasing wetness, the hypothesis that changes in the lacustrine water could be due to increasing temperature favoring an increase in nutrients seems strongly supported. Mesophilous vegetation shows a continuous increasing trend that can be related to the rise in humidity suggested by $\delta^{18} \mathrm{O}_{\text {carb }}$ at the end of the zone. Low concentration values of microcharcoals indicate the absence of local fire and sporadic regional ones. Low fire activity is also indicated by biomarkers with a low concentration of polycyclic aromatic hydrocarbon (PAH).

\subsection{Pollen zone D-4 (483-443 cm, 10 150-9400 yr BP, duration 750 years)}

AP \% ranges from 62 to $76 \%$. Total pollen concentration (pollen grains $\mathrm{g}^{-1}$ ) varies between ca. 57900 and 250700 , influx values between ca. 3200 and 11600 and the number of taxa between 31 and 49. Mesophilous vegetation dominates in the pollen zone. Deciduous oaks (26-41\%) record a minimum at $9700 \mathrm{yr}$ BP in correspondence with an increase in Poaceae $(5-16 \%)$ and semi-evergreen oaks (2$16 \%)$. Among aquatic plants, Alisma (>0-3\%) shows its 


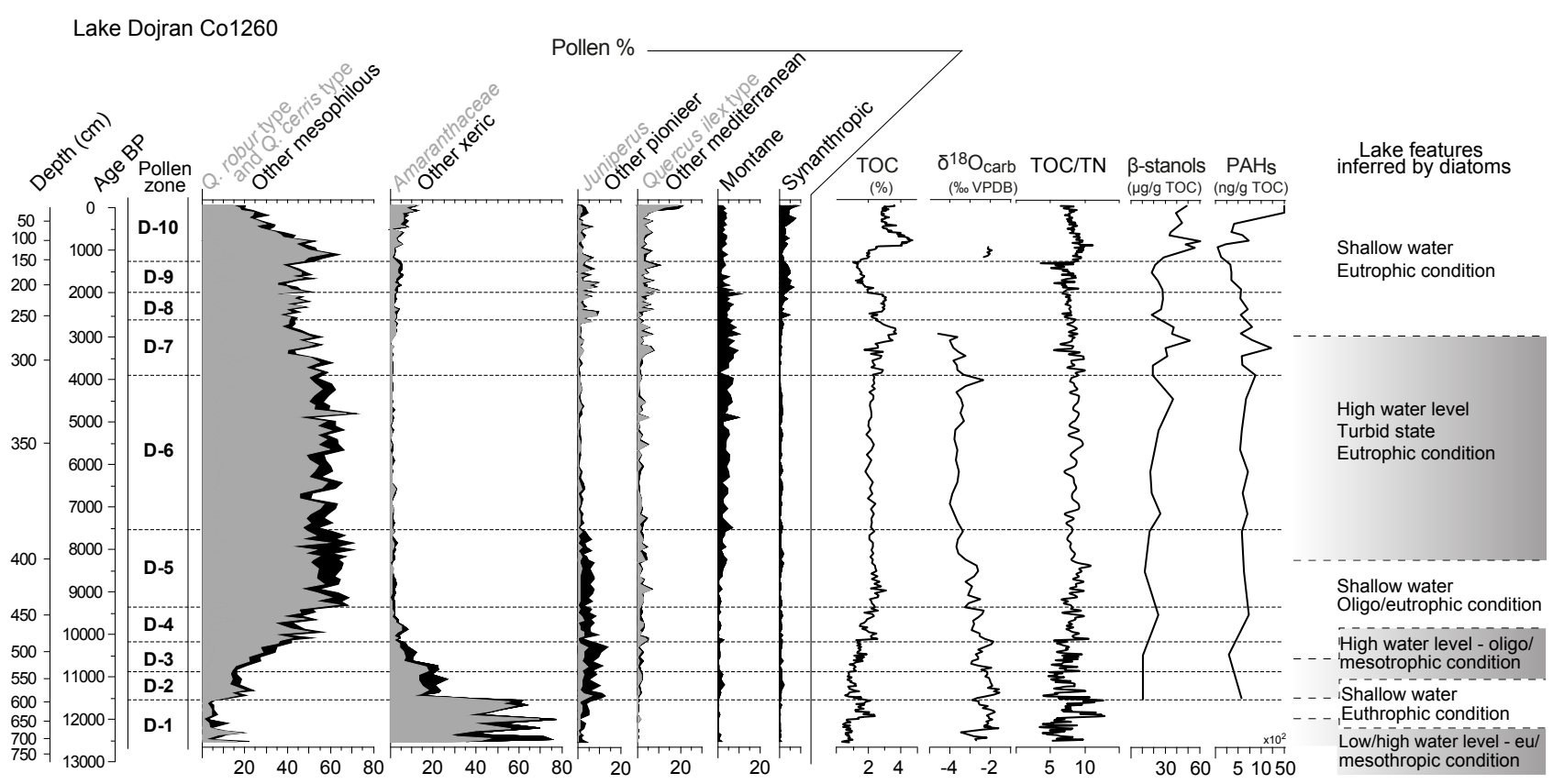

Figure 4. Pollen percentage diagrams of plant groups. Mesophilous: Acer, Buxus, Carpinus betulus, Celtis, Corylus, Fraxinus excelsioroxycarpa, Hedera, Ostrya-Carpinus orientalis, Quercus robur type, Quercus cerris type, Tilia, Ulmus. Xeric: Amaranthaceae, Artemisia, Helianthemum. Pioneer: Betula, Corylus, Ephedra, Juniperus, Rosaceae. Mediterranean: Arbutus, Fraxinus ornus, Cistus, Pistacia, Phillyrea, Quercus ilex type, Rhamnus. Montane: Abies, Betula, Fagus. Synanthropic: Castanea, Centaurea cyanus, cereals (Secale, Triticum, Hordeum), Juglans, Olea, Plantago lanceolata, Rumex, Trifolium, Vitis. Comparison of pollen data with selected geochemical data (Francke et al., 2013a); biomarker curves (Thienemann et al., 2017) and lake features inferred by diatom data (Zhang et al., 2014) of Lake Dojran.

highest value. The reduction in deciduous oaks matches a minimum in planktonic diatoms and in total diatom concentration. Pioneer taxa are on the whole reduced, with Rosaceae undiff. (1-5\%) still important and Corylus (0-4\%) increasing. Xeric taxa (Artemisia, 1-3\%; Amaranthaceae, 1-5\%; Juniperus, $0-3 \%)$ and Asteroideae undiff. (1-4\%) are reduced. Pine is between 7 and $14 \%$. High values of Galium $(0-5 \%)$ and significant values of Lamiaceae $(0-3 \%)$ are still found, with a spread of Sanguisorba cf. minor (1$7 \%)$ as well. Abies $(0-1 \%)$ shows a sporadic presence since $9800 \mathrm{yr}$ BP. Microcharcoals indicate the presence of both regional and local fires. According to the pollen assemblage and sedimentological data, this time period was characterized by increasing humidity, in particular during summer. However, diatoms suggest low lake levels.

\subsection{Pollen zone D-5 (439-385 cm, 9300-7600 yr BP, duration 1700 years)}

AP \% ranges from 76 to $93 \%$. Total pollen concentration (pollen grains $\mathrm{g}^{-1}$ ) varies between ca. 125800 and 342 200, influx values between ca. 3700 and 13500 and the number of taxa between 29 and 40. The Quercus robur type is dominant, with oscillation from 34 to $51 \%$ and high influx values, in particular at $9000 \mathrm{yr}$ BP. The other woodland elements (Quercus cerris type, 3-15\%; Ostrya-Carpinus orien- talis, 1-9\%; Corylus, 1-6\%), together with the first sporadic traces of Carpinus betulus ( $0-4 \%$ ), indicate rising temperature. Fagus is more continuously present all over the zone even if with values below $1 \%$. In general, the rising value of AP \% is related to the increase in Abies (0-4\%), OstryaCarpinus orientalis and in particular of Pinus that triples its amount along this zone from 6 to $20 \%$. In contrast, none of the Mediterranean taxa increase. The rising of pine together with fir suggests that they both come from mountain species organized in altitudinal belts. Denser forest canopy (AP $89 \%$ at $8400 \mathrm{yr}$ BP) matches a wetness increase indicated by lower $\delta^{18} \mathrm{O}_{\text {carb }}$ and a change in lake level suggested by diatoms (from shallow to high stands). Alisma (>0-2\%) is attested at the very beginning of this zone. Turbid water inferred from diatoms was probably responsible for decreased Pediastrum, as a whole changing from $41 \%$ at $8700 \mathrm{yr} \mathrm{BP}$ to $3 \%$ at $8200 \mathrm{yr}$ BP. Among the herbs, Poaceae (2-9\%) still prevail together with Sanguisorba cf. minor (1-7\%), but both of them show a decreasing trend.

\subsection{Pollen zone D-6 (383-315 cm, 7500-4000 yr BP, duration 3500 years)}

AP \% ranges from 84 to $94 \%$. Total pollen concentration (pollen grains $\mathrm{g}^{-1}$ ) varies between ca. 200900 and 692300 , the highest value of the record, influx values be- 
tween ca. 3500 and 12600 and the number of taxa between 25 and 40. Mesophilous vegetation is well attested during the mid-Holocene. The arboreal pollen percentages are always around $90 \%$. The Quercus robur type dominates (35$61 \%$ ), followed by Pinus (16-31\%), the Quercus cerris type (4-15\%), Abies (2-9\%) and Ostrya-Carpinus orientalis (1-6\%). Cereals show some intermittent presence since 4900 yr BP. Montane taxa are quite well represented, in particular Abies. Mediterranean vegetation shows minimum values. Palynological data indicate a stable climate with a high lake level and humid conditions, which is confirmed by diatom, sedimentological and $\delta^{18} \mathrm{O}_{\text {carb }}$ data. Relatively stable conditions are also visible from the biomarker records. In addition, diatoms point to a eutrophic state of the lake. The littoral vegetation belt was limited as indicated by the low amount of Poaceae (2-9\%). Other herbs show low values. Cereals $(>0 \%)$ show a continuous presence between 5000 and $4800 \mathrm{yr}$ BP. In this zone, Pediastrum still has low values related to the permanence of turbid water. Different sizes of charcoal attests the presence of regional and local fires.

\subsection{Pollen zone D-7 (311-257 cm, 3900-2650 yr BP, duration 1250 years)}

AP \% reach the highest values in this zone; it ranges from 82 to $95 \%$. Total pollen concentration (pollen grains $\mathrm{g}^{-1}$ ) varies between ca. 90200 and 315200 , influx values between ca. 5100 and 13700 and the number of taxa between 26 and 42. Pollen data register a rapid increase in Pinus (21-35\%), reaching the highest values of the whole sequence, and decreased values of the Quercus robur type (29-46\%) that always dominates. Fagus presence ( $>0-3 \%$ ), among montane taxa slightly increasing, is definitively attested after a very slow increase since ca. $6000 \mathrm{yr}$ BP. Other arboreal plants are the Quercus cerris type (4-22\%), Abies (0-10\%) and the Quercus ilex type (>0-6\%). Gradual environmental changes can be addressed for the increase in Mediterranean (mainly due to evergreen oaks) and xeric taxa. Since $3000 \mathrm{yr}$ BP, the latter show values higher than $5 \%$. The occurrence of such high values was recorded at $9900 \mathrm{yr}$ BP for the last time. Cereals $(<1 \%)$ are almost continuously present since 3600 yr BP. Planktonic diatoms strongly decrease soon after $3000 \mathrm{yr} \mathrm{BP}$, indicating lake shallowing. Curves of Pediastrum taxa fluctuate, showing increases since the bottom of the zone D-7, suggesting water eutrophication. In particular, $P$. boryanum matches the fecal stanol (produced in the gut of mammals) record, suggesting a correspondence between humans, pasture and an increase in nutrients in water. Geochemical data attest distinct changes in some proxies, suggesting high instability. In particular, the $\mathrm{C} / \mathrm{N}$ ratio shows a significant increase in nutrients at $3200 \mathrm{yr}$ BP. At the same time, clastic matter deposition starts to increase, suggesting intensive erosion in the catchment.

\subsection{Pollen zone D-8 (253-217 cm, 2600-2000 yr BP, duration 600 years)}

AP \% ranges from 83 to $90 \%$. Total pollen concentration (pollen grains $\mathrm{g}^{-1}$ ) varies between ca. 75200 and 383300 , influx values between ca. 4400 and 25800 and the number of taxa between 28 and 44. An important vegetation change is suggested by the rapid increase in pioneer taxa, mostly $J u$ niperus $(>0-8 \%)$. This indicates deterioration of the forest ecosystems even if AP \% is only slightly reduced. Abies (2$7 \%$ ) begins to decline. The Quercus robur type (25-39\%) and Pinus (22-35\%) are dominant and accompanied by the Quercus cerris type (4-14\%), the Quercus ilex type (0-7\%), Fagus (>0-4\%) and Ostrya-Carpinus orientalis (1-3\%). Among arboreal plants, Olea (0-2\%), Juglans (0-1\%) and Castanea (0-1\%) appear to be more continuous than in previous zones. These three taxa are sporadically present since the early Holocene but show a clear increase since around $2500 \mathrm{yr}$ BP. Olea is the first taxon to increase, followed soon after by Juglans and then by Castanea. Their contemporary and increased presence can be taken as evidence of cultivation (Mercuri et al., 2013a). This hypothesis is supported by the expansion of cereals (reaching $4 \%$ ) and the sporadic presence of Plantago since the bottom zone. The pollen assemblage suggests the use of agricultural practices. This hypothesis is confirmed by increased Glomus, suggesting soil erosion. Charcoals attesting regional fires are documented all over the zone. Diatom assemblages are evidence of shallow water and eutrophic conditions, which is confirmed by similar trends in fecal stanols and Pediastrum boryanum. At 2400 yr BP, the expansion of Pediastrum simplex var. sturmii could be an indication of increasing water temperature.

\subsection{Pollen zone D-9 (213-161 cm, 2000-1400 yr BP, duration 600 years)}

AP $\%$ ranges from 65 to $81 \%$. Total pollen concentration (pollen grains $\mathrm{g}^{-1}$ ) varies between ca. 33400 and 126200, influx values between ca. 2800 and 9600 and the number of taxa between 40 and 50. At the beginning of the zone, the arboreal vegetation rapidly drops due to the abrupt decline of Pinus (from 18 to $5 \%$, from 50000 to 17000 pollen grains $\mathrm{g}^{-1}$ ) accompanied by a slower reduction of Abies (from 7 to $1 \%$, from 10000 to 1000 pollen grains $\mathrm{g}^{-1}$ ). Even though not at a similar amplitude, there are clearly similar patterns in many taxa both in concentration and influx data. Most taxa, including oaks, appear to be affected by a strong biomass decrease, even if it occurs slightly earlier than in the two mentioned conifers. The decrease started at the end of zone D-8 for the Quercus robur type (38 to $26 \%$, from 113000 to 37000 pollen grains $\mathrm{g}^{-1}$ ) and the Quercus cerris type (from 7 to 6\%, 113000 to 37000 pollen grains) that reach lower values ca. 50 years before the drop in pine and fir. Pioneer, xeric and synanthropic taxa increase in the zone. Human presence is indicated by 
the high amount of synanthropic plants such as cultivated (e.g., cereals, 0-3\%; Castanea, 0-1\%; Olea; Juglans) and ruderal ones (Plantago, 0-2; Rumex, 0-2; Urtica, >0-2). Forest clearance and the relatively high amount of xeric taxa, mainly Artemisia (1-2\%), can either be the consequence of increased aridity or human impact. The increase in Poaceae (7-15\%) and Amaranthaceae (2-5\%) could be due to low lake stands and the relative enlargement of shallow areas covered by reed beds. The productivity in the lake seems to be rather important as evidenced by TOC / TN and diatom assemblages. Charcoal assemblages show that regional and local fires are of scarce importance.

\subsection{Pollen zone D-10 (153-0 cm, 1250 yr BP-present, duration 1200 years)}

AP \% ranges from 60 to $86 \%$. Total pollen concentration (pollen grains $\mathrm{g}^{-1}$ ) varies between ca. 55000 and 230900 , influx values between ca. 6500 and 25600 and the number of taxa between 32 and 55. Mesophilous taxa drop. This change is mainly due to the decreasing Quercus robur type (8-39\%) and Quercus cerris type (3-16\%), while Carpinus betulus shows moderate alternations with values $(>0$ $4 \%$ ) as high as in OD-5. Mediterranean taxa increase, peaking in the last samples. This increase is mainly due to the Quercus ilex type (1-19\%), but also to Olea (0-4\%). Pinus (7-26\%) recovered and reaches $26 \%$ at about $500 \mathrm{yr} \mathrm{BP}$. Abies remains below $2 \%$, suggesting that higher-altitude environments do not easily recover, being more fragile. Xeric (mainly Amaranthaceae, 0-11\%) and synanthropic taxa increase along the whole zone, in particular since $500 \mathrm{yr}$ BP. Artemisia shows rather high values in the second part of the zone. Amaranthaceae, included in the sum of xeric taxa, can also include ruderal herbs. The proximity of the lake is colonized by arboreal riparian vegetation, mainly Alnus (max $2 \%$ ). Poaceae could form a Phragmites belt around the lake like today. Shallow lake conditions are inferred from diatoms and Myriophyllum. This water plant generally grows in water up to $2 \mathrm{~m}$ deep (Azzella and Scarfó, 2010). Increasing temperature and eutrophic water have also been evidenced by the rising of Pediastrum taxa. Bottema et al. (1974) associated the increase in Pediastrum simplex with soil fertilization due to cattle. In the same period, biomarkers (especially the fecal stanol record) indicate strong anthropogenic impact in the catchment. Concentration and influx values of charcoal are the highest of the diagram for regional fires between 1000 and $1300 \mathrm{yr}$ BP. The last part of the pollen record reflects the increasing human impact and the consequences of the recent tendencies in shaping the landscape around the lake.

\section{General discussion and multi-proxy comparison}

The Lake Dojran pollen sequence starts during the Late Glacial with the dominance of xeric taxa. Most arboreal plants are present at the bottom of the core, suggesting the presence of glacial refugia for montane and mesophilous taxa in the catchment of Lake Dojran. In particular, Pinus, the Quercus robur type and Ostrya-Carpinus orientalis peaks are recorded before $12000 \mathrm{yr}$ BP. The fluctuating presence of coniferous and deciduous taxa in glacial periods is recorded in several lakes of the central-eastern Mediterranean: Prespa (Panagiotopoulos et al., 2013), Ohrid (Sadori et al., 2016b), Ljubljana (Willis, 1994), Ioannina (Bottema et al., 1974; Tzedakis, 1994), Bulgarian mountain lakes (Tonkov and Marinova, 2005; Tonkov et al., 2008, 2016), Monticchio (Allen et al., 2009), Vico (Magri and Sadori, 1999), Pergusa (Sadori and Narcisi, 2001), Trifoglietti (De Beaulieu et al., 2017) and Van (Litt et al., 2009).

The onset of Holocene reforestation is dated at Dojran to $11500 \mathrm{BP}$ and infers increasing humidity and temperature. The data show the decline of steppe-related plants and also the presence of pioneer trees such as Rosaceae, Juniperus and Betula that constitute forest patches accompanied by $\mathrm{Pi}$ nus and by all oak types. This behavior is typical of the succession from glacial to interglacial phases in Southern Europe (Tzedakis, 2007), as shown in Fig. 5, in which some of the available records are shown. Similarly to other lacustrine sites (Prespa, Panagiotopoulos et al., 2013; Ioannina, Lawson et al., 2004; Pergusa, Sadori and Narcisi, 2001), a couple of millennia are needed at Dojran to achieve $80 \%$ of AP in zone D-5 at ca. $9300 \mathrm{yr}$ BP, showing fairly resilient ecosystems. In particular, rising humidity is evidenced for Lake Van (Litt et al., 2009) by the increasing trend of deciduous (and semi-deciduous) oaks. In pollen zone D-2 (ca. $11500-$ $10900 \mathrm{yr}$ BP) the AP trend shows a first start soon followed by a decrease in the percentage of mesophilous taxa that deserves consideration. It is due to a decrease in the Quercus robur type partly balanced by an increase in the $Q$. cerris type (peaking at $11100 \mathrm{yr} \mathrm{BP}$ ). This shift between the two oak types was probably a signal of a temporary reduction of humidity, a sort of short-term stasis of forest expansion. A similar pattern (evidenced in Fig. 5) is observed at Prespa (Panagiotopoulos et al., 2013) and Ioannina (Lawson et al., 2004) in the Balkans and at Vico (Magri and Sadori, 1999) and Pergusa (Sadori and Narcisi, 2001) in Italy. It is likely to be synchronous, and secular differences can be attributed to uncertainties in each site's age model. The pattern of zone D-2 seems to be repeated once more at Dojran in zone D-4 (10 200-9400 yr BP), where a similarity in mesophilous taxa and TOC curve trends is found (Fig. 4). This forest opening is probably less pronounced at other sites, but it matches an important change detected at higher elevations from "wetter" to "drier" taxa. At Lake Trilistnika (Tonkov et al., 2008), after a short and sharp increase in Abies soon followed by the Quercus robur type, the Quercus cerris type prevails.

The forest is definitely established at ca. $9300 \mathrm{yr}$ BP (beginning of zone D-5) with AP at $80 \%$, increased pollen concentration and influx values and relatively increasing TOC (Figs. 3 and 4; Francke et al., 2013a). The rising AP \% is paralleled by a decreasing trend in the average chain length of 


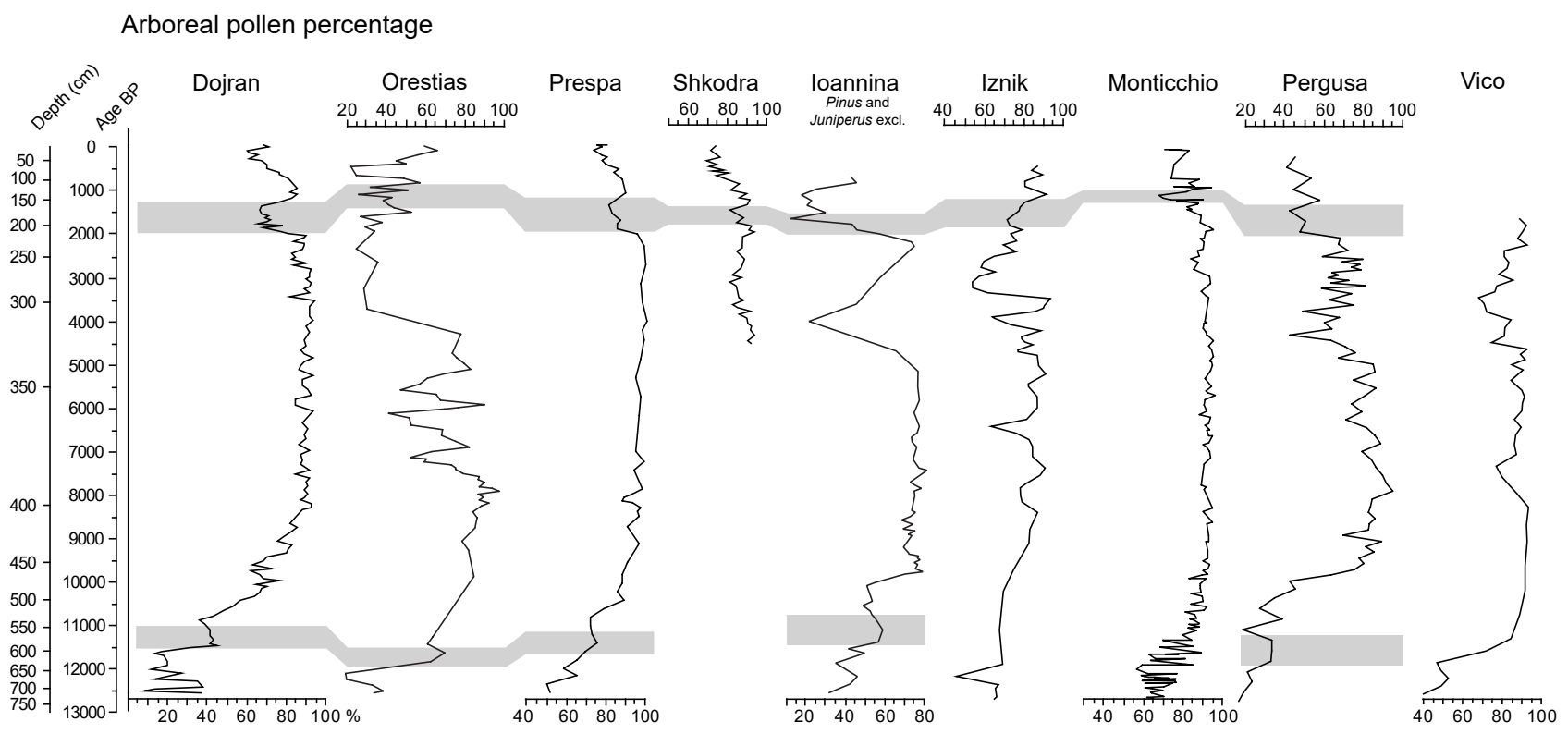

Figure 5. Arboreal pollen percentage diagram from Lake Dojran, Lake Prespa, Ioannina basin, Lake Pergusa, Lake Iznik, Lago Grande di Monticchio, Lake Vico, Orestiás and Lake Shkodra. See text for references.

vascular plant $\mathrm{n}$-alkanes, also indicating increasing arboreal vegetation (Thienemann et al., 2017). Pioneer taxa, with the exception of wet-demanding Corylus that is increasing, and the light-demanding Sanguisorba cf. minor were replaced first by Abies and then at ca. $8500 \mathrm{yr}$ BP by Ostrya-Carpinus orientalis and Carpinus betulus. This forest succession, resulting in an increase in "other mesophilous" and montane taxa (Fig. 4), matches the enhanced humidity $\left(\delta^{18} \mathrm{O}_{\text {carb }}\right)$ and high lake level inferred from diatoms. The latter is also confirmed by decreasing Poaceae, which may indicate a reduction of the lacustrine vegetation belt formed by Phragmites and/or Paspalum. The increase in humidity probably allowed for the colonization of higher altitudes and resulted in the definitive attestation of vegetation belts. Even if temperate deciduous forest prevails, mountain taxa such as Abies and Fagus probably partly replaced pioneer ones on the two mountain chains (Belles and Krousia) surrounding the lake. Arboreal vegetation (and deciduous oaks above all) prevails not only at Lake Dojran but also at other regions in the eastern and central Mediterranean, such as at Lake Prespa (Panagiotopoulos et al., 2013), in the Ioannina basin (Lawson et al., 2004), at Tenaghi Philippon (Müller et al., 2011), at Lake Iznik (Miebach et al., 2016), at Eski Acigöl (Woldring and Bottema, 2003), at Lake Van (Litt et al., 2009) and at Lake Pergusa (Sadori and Narcisi, 2001; Sadori et al., 2013).

The pollen assemblages of Lake Dojran show no clear evidence of the $8.2 \mathrm{ka}$ cooling event. The zone shows rather stable vegetation conditions and a very low sedimentation rate. The event is considered the most prominent and abrupt climate change at the northern latitudes of the entire Holocene (Johnsen et al., 2001). Only some of the Mediterranean pollen records (Lake Maliq: Bordon et al., 2009; Tenaghi Philippon: Pross et al., 2009) register the 8.2 event, usually consisting of a more or less pronounced short phase with reduced precipitation (e.g., Staubwasser and Weiss, 2006; Kotthoff et al., 2008; Pross et al., 2009; Göktürk et al., 2011; Miebach et al., 2016). It is interesting to note that hydroacoustic data indicate a low lake level centered at $8.2 \mathrm{ka}$ (Francke et al., 2013a) supported by a reduction of Poaceae. Water could be partially trapped in wider or longer-persisting snow cover in the mountains. The amount of Mediterranean plants is low, indicating that the water availability is related to a temperate climate and the abundance of mesophilous plants indicates wet conditions. Pross et al. (2009) suggest a thermal gradient between inland and coastal settings in the Aegean Sea with weaker winter cooling at the coast. The connection of the Dojran area with Mediterranean Sea could have mitigated the temperature reduction that, together with the resilience of vegetation, could have masked the 8.2 event impact.

Traces of synanthropic plants, including cereals, Juglans and Rumex, are found since $5000 \mathrm{yr} \mathrm{BP}$. Biomarker data also possibly indicate the first human activities around $4500 \mathrm{yr} B P$ (Thienemann et al., 2017). Athanasiadis et al. (2000) found clear signs for the first human activity at that time in two cores from the eastern edge of the lake. Co1260 (this article) was recovered from a central position in the lake and records the onset of human settlements as less pronounced, probably due to a higher distance from these settlements. However, the presence of cereals can be taken as an indication of cultivation in the area that was populated since the early Neolithic due to the migration of populations from Anato- 
lia and nearby Greece performing livestock farming (Kaiser and Voytek, 1983). A wide range of cereals and legumes are attested in the archaeological excavation of Anza (ca. 6500$5000 \mathrm{yr}$ BC) in FYROM for the Neolithic (Gimbutas, 1974). In the nearby Struma Valley (Bulgaria) the size and number of archaeological sites increase, indicating a strong increase in population, particularly in the second half of the Late Neolithic (5200-4900yr BC; Marinova et al., 2012). Archaeological remains evidence a new increase in sedentarism during the Bronze Age, with increasing agriculture practices (Kokkinidou and Trantalidou, 1991). In Lake Dojran sediments, Juglans is attested for the first time at around $7000 \mathrm{yr} \mathrm{BP}$, which is in agreement with a recent paper by Pollegioni et al. (2017) stating that the first exchanges of germplasm between the Near East and Aegean region are dated at the 6th millennium BP. Contemporary presence is sporadically recorded at Lake Ribno Banderishko (southwestern Bulgaria; Tonkov et al., 2002), while major quantities are found at Orestiás (Kouli, 2015). In contrast at Shkodra, Prespa and in previous data from Dojran, Juglans is attested only since $3500 \mathrm{yr}$ BP in more significant quantities. The early presence of walnut in the Dojran record can be related to the economic exchange that would have spread the plant from the Near East through Turkey to Europe. The walnut tree is in fact valuable not only for the edible fruit but also for timber.

At ca. 4000 yr BP, a sharp influx and concentration drop matches an increase in Pinus, marking the start of zone D7 and suggesting decreasing humidity. AP \% remains rather stable, probably due to the expansion of Pinus. This change in forest composition probably favored the slight increase in Fagus. The other proxies available at Dojran, which are not affected by human impact, also suggest aridification

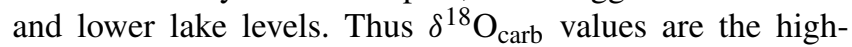
est of the last 9500 years, and planktonic diatoms decrease strongly. Biomarker data also indicate a drier climate around 4000 yr BP. Forest opening, occurring soon before and culminating at $4000 \mathrm{yr} \mathrm{BP}$, is indicated in most pollen records, as shown in Fig. 5, pointing out that the phenomenon is present both in the Italian and Balkan peninsulas and is strictly related to regions under Mediterranean influence. In fact, aridification is missing both at Lake Van (Litt et al., 2009) and in the central Rila Mountains in Bulgaria where Picea shows an increasing trend since $5000 \mathrm{yr}$ BP (Tonkov et al., 2016). Moreover, it is still under debate whether this change is caused by climatic change or is human induced. In central Italy, a decrease in humidity detected soon before $4000 \mathrm{yr}$ BP is found in low-stand lake levels (Giraudi et al., 2011) and in speleothems (Zanchetta et al., 2016). This change in hydrology and seasonality (longer summer drought) surely affected forest plants, especially mesophilous taxa. Animal husbandry, cultivation and metallurgy were probably intensifying and accelerating the phenomenon (Sadori et al., 2004), causing forest clearance all over the central Mediterranean area (Denéfle et al., 2000; Jahns, 2005; Caroli et al., 2007;
Sadori et al., 2008; Bordon et al., 2009; Di Rita and Magri, 2009; Tinner et al., 2009; Combourieu-Nebout et al., 2013; Mercuri et al., 2012, 2013a). A major role is also to be ascribed to fire, which increased in the whole Mediterranean area (Vanniére et al., 2011; Sadori et al., 2015b). According to some authors, the use of fire and the anthropogenic degradation of forest (Marinova et al., 2012) could have favored the spread of Fagus, but a climate-driven cause should also be taken into account (Giesecke et al., 2007; Valsecchi et al., 2008).

Since $2600 \mathrm{yr}$ BP, the Lake Dojran pollen assemblage shows a considerable expansion of anthropogenic indicator taxa (the synanthropic non-cultivated and cultivated plants described by Behre et al., 1990). Littoral cores studied by Athanasiadis et al. (2000) record primary and secondary anthropogenic indicators (mainly Triticum type and Secale) since ca. $3500 \mathrm{yr}$ BP with a lower percentage. Another major vegetation change around this date is an expansion of $J u$ niperus that probably replaced the mesophilous forest disturbed by human activity. Also, several arboreal cultivated taxa increase in zone D-8: Castanea, Juglans and Olea. Mercuri et al. (2013a) introduced the OJC (Olea, Juglans, Castanea) sum to highlight the increasing human activity in the Mediterranean area, as these trees increase from the Bronze Age onwards all over Italy. Mercuri et al. (2013b) made a step forward by adding seven selected anthropogenic nonarboreal pollen indicators (APIs) common in archaeological sites to investigate the shaping of the cultural landscape (Marignani et al., 2017).

At Lake Dojran, cereal percentages are low but quite significant (around 5\%) and attest a well-developed agricultural system (Sadori et al., 2016a). This is due to self-pollination and the consequent under-representation in pollen diagrams (van Zeist et al., 1975; Fægri and Iversen, 1989). Pollen related to grazing or disturbed areas like Plantago lanceolata and Rumex are very scarce. Pasture land was probably reduced, while agriculture seems to have played an important role in the economy. Marinova et al. (2012) pointed out that after a period with no archaeological evidence, a remarkable socioeconomical expansion is attested since the 6th century $\mathrm{BC}$ at around $2500 \mathrm{yr} \mathrm{BP}$.

Either a climate change or a large-scale human impact can be invoked to explain the strong reduction of Pinus and Abies that occurred during D-9 after 2000 yr BP. First Greeks, followed by Romans and Byzantines could have regionally cut them for the valuable timber. Macedonia was indeed an important region for timber harvesting since the 5th century AD and probably earlier. Fir and pine were the standard ship timber, and naval power depended on them (Harris, 2013). Their pronounced decrease is again related to the presence of $J u$ niperus that typically takes advantage in more degraded environments. At the same time, both the concentration and influx reach very low values, mirroring decreasing PAHs. Cereal, Castanea, Juglans and Olea cultivation together with ruderal and weed taxa attest a strong human impact. His- 
torical reconstructions confirm that in Macedonia the culmination of the growth in both cereals and walnut occurred during the mid-Roman and Late Antiquity periods (1650$1500 \mathrm{yr}$ BP; Izdebski et al., 2015).

A strong reduction of AP \% (Fig. 5), caused by a decrease in oaks or pines, is found at many sites around $2000 \mathrm{BP}$. In particular, a Pinus drop is found at Prespa at $2300 \mathrm{yr} \mathrm{BP}$ (Panagiotopoulos et al., 2013), at Trilistnika at $2000 \mathrm{yr} \mathrm{BP}$ (Tonkov et al., 2008) and probably also at Eski Acigöl (Woldring and Bottema, 2003) even if for the Turkish site the chronology remains uncertain. In all sites this change marks forest reduction. It can once more be interpreted either as a transition from wetter to drier conditions or as a strong human-induced forest clearance. Climatic data are available from tree-ring-based reconstructions of Central Europe (Büntgen et al., 2011). The authors rule out a decrease in total reconstructed precipitation and temperature anomalies at $2100 \mathrm{yr}$ BP. A global climate change seems, however, to be ruled out for this period (Bond et al., 1997).

The new spread of Pinus occurring in D-10 might not indicate a recovery of the forest as mesophilous tree percentages are decreasing. Pines can in fact have a pioneer role in anthropogenic-influenced landscapes (Litt et al., 2012), as they quickly grow in degraded areas such as those colonized by junipers. At ca. $700 \mathrm{yr}$ BP, high pollen concentration and influx values match high TOC, increased polycyclic aromatic hydrocarbon and fecal stanol concentrations and the slightly increased Cichorioideae that could be related to pastoralism (Florenzano et al., 2015). Although decreased temperatures are detected in geochemical proxies, the Little Ice Age (LIA) is not evident in pollen data. The LIA could be seen in the forest recovery indicated by increasing influx values (Fig. 3) but not in the pollen percentage assemblage that still remains high. Strong human activities consisting of livestock farming, fire use and cultivation may mask the climate signal and overlap the natural changes of the LIA. Strong land use is still present in the top samples, with hints of Olea, Juglans and Vitis cultivation in the last few centuries. The expansion of these taxa corresponds to the economic and demographic one reported by Gogou et al. (2016) at around $900 \mathrm{yr} \mathrm{BP}$ as a consequence of a new political order, when the Macedonian region became of central importance for the Byzantine Empire. Olea and Vitis cultivation has been and still is of primary importance in the Byzantine diet (Xoplaki et al., 2016). Grapes are currently the primary product of the Dojran area, even if today there are few farms growing Vitis vinifera on altogether 263 ha (Bojovic et al., 2016). The increase in Poaceae recorded in D-10 can be ascribed to the presence of a littoral belt. Modern vegetation suggests the presence of either Paspalum distichum (water finger grass) or Phragmites australis (common reed). Common reeds have been recently used in the area for different purposes, primarily to produce special traps for fishing (Bojovic et al., 2016).

\section{Conclusions}

The new high-resolution pollen record from Lake Dojran draws the vegetation history of the area between FYROM and Greece for the last 12500 years, evidencing the regional response to climate forcing. The pollen record covers the environmental changes from the Late Glacial until today passing from a natural undisturbed landscape to one in which increasing anthropogenic influences overlap climate change. These new data, together with sedimentological, biomarker and diatom data available from the same core, highly contribute to a better understanding of the environmental history, including both climatic and human evidence.

A steppe characterized by Amaranthaceae, Artemisia and Poaceae prevails during the Late Glacial period. The beginning of the Holocene reforestation at Lake Dojran is dated at $11500 \mathrm{yr}$ BP, which is similar to other Mediterranean records. It consists of a false start of AP also found in other sites, like Orestiás, Lake Prespa, Ioannina and Lake Pergusa, and preceding the real expansion of the Holocene forest. Two millennia were necessary to reach maturity in the forests dominated by deciduous Quercus. Mesophilous vegetation dominated for the entire Holocene, but a welldeveloped forest is found until ca. $4000 \mathrm{yr} \mathrm{BP}$. The first human traces are recorded around $5000 \mathrm{yr}$ BP with the presence of cereals, Juglans and Rumex. Synanthropic taxa rise considerably during the Bronze Age and particularly in the Roman age. Around $2000 \mathrm{yr}$ BP, the arboreal pollen and mainly Pinus show a strong reduction that is detectable at most sites of the Mediterranean basin. Even if the attestation of drier conditions can be advocated to explain the abrupt change in vegetation, the forest clearance made by the Roman Empire would have been strong enough to affect vegetation on a regional scale. Present day vegetation is human influenced, but the natural vegetation is still preserved, confirming the importance of the region as a biodiversity conservation area.

The comparison of the Dojran pollen record with the regional ones evidences similarities in the reafforestation dynamics at the beginning of the Holocene. The detailed sequence clarifies and better describes some peculiarities like the characteristic interruption in afforestation at the beginning of the Holocene (between ca. 10800 and $11500 \mathrm{yr} \mathrm{BP}$ ). Although this behavior was present in other proxies, the Dojran sequence clearly evidences this dynamic, allowing for the identification of the same behavior in the region. The high arboreal cover that characterized the mid-Holocene is more evident at Dojran where the fluctuations in the arboreal pollen percentage are minimal despite the high analytical detail. Finally, the clear AP decrease related to the strong reduction of pine since $2200 \mathrm{yr}$ BP is now detectable in the regional proxies to which it has been linked. The presented data represent the first Late Glacial and Holocene continuous sequence of Lake Dojran. The high-resolution pollen analysis and the available multi-proxy dataset provide a unique contribution to the reconstruction of vegetation dynamics and 
their relationship with paleoenvironmental changes and the human impact of the entire region.

Data availability. All the pollen data published in the present paper are available through the online database Pangaea at https://doi.org/10.1594/PANGAEA.885797 (Masi et al., 2017). All the geochemical data already published by Francke et al. (2013a) are available through the same database (https://doi.org/10.1594/PANGAEA.860791; Francke et al., 2013b). The biomarkers shown in Fig. 4 and published by Thienemann et al. (2017) are available through the same database at https://doi.org/10.1594/PANGAEA.885797 (Masi et al., 2017).

Author contributions. The paper was written by AM (all sections) and LS (Sects. 2, 4, 5, 6) with the substantial contribution of BW (Sects. 1, 5, 6), AF (Sects. 4, 5, 6) and MT (Sects. 4, 5, 6). Pollen analysis was carried out by AM with the contribution of $\mathrm{CP}$ for the chemical procedure and microscope identification. AM is responsible for data management and the elaboration of figures and diagrams.

Competing interests. The authors declare that they have no conflict of interest.

Special issue statement. This article is part of the special issue "Global Challenges for our Common Future: a paleoscience perspective" - PAGES Young Scientists Meeting 2017. It is a result of the 3rd Young Scientists Meeting (YSM), Morillo de Tou, Spain, 7-9 May 2017.

Acknowledgements. We would like to thank all the authors of the papers on sedimentological and stable isotope (Francke et al., 2013a), diatom (Zhang et al., 2014) and biomarker data (Thienemann et al., 2017) of Lake Dojran that have been invaluable in the interpretation of pollen data. We are grateful to Katerina Kouli and Kostantinos Panagiotopoulos for providing pollen data of Lake Orestiás and Prespa. We express gratitude to Vlado Matevski for support with the description of the modern vegetation of the Dojran area.

Edited by: Robert Barnett

Reviewed by: Anna Maria Mercuri and one anonymous referee

\section{References}

Allen, J. R. M. and Huntley, B.: Last Interglacial palaeovegetation, palaeoenvironments and chronology: a new record from Lago Grande di Monticchio, southern Italy, Quaternary Sci. Rev., 28, 1521-1538, 2009.

Andersen, S. T.: Identification of wild grasses and cereal pollen, in: Danmarks Geologiske Undersøgelse, Årbog, Copenhagen, Denmark, 69-92, 1979.
Athanasiadis, N., Tonkov, S., Atanassova, J., and Bozilova E.: Palynological study of Holocene sediments from Lake Doirani in northern Greece, J. Paleolimnol., 24, 331-342, 2000.

Azzella, M. M. and Scarfó, F.: Atlante della vegetazione ripariale e sommersa della Riserva Naturale Lago di Vico, Collana Atlanti Locali, edizioni ARP, Roma, 2010.

Berglund, B. E. and Ralska-Jasiewiczowa, M.: Pollen analysis and pollen diagrams, in: Handbook of Holocene Palaeoecology and Palaeohydrology, edited by: Berglund, B. E., John Wiley \& Sons, Chichester, 455-496, 1986.

Behre, K.-E.: Some reflections on anthropogenic indicators and the record of prehistoric occupation phases in pollen diagrams from the Near East, in: Man's Role in the Shaping of the Eastern Mediterranean Landscape, edited by: Bottema, S., EntjesNieborg, G., and van Zeist, W., Balkema, Rotterdam, 219-230, 1990.

Bojovic, D., Ilieva, L., and Giupponi, G.: Intergraded Water Resource Management at Dojran Lake in Macedonia, EuroMediterranean Centre on Climate Change (CMCC), Technical Report, https://doi.org/10.13140/RG.2.2.27462.27204, 2016.

Bottema, S.: Late-quaternary vegetation history of Northwestern Greece, Proefschr., Rijksuniv. Groningen, 190 pp., 1974.

Bond, G., Showers, W., Cheseby, M., Lotti, R., Almasi, P., deMenocal, P., Priore, P., Cullen, H., Hajdas, I., and Bonani, G.: A Pervasive Millennial-Scale Cycle in North Atlantic Holocene and Glacial Climates, Science, 278, 1257-1266, 1997.

Bordon, A., Peyron, O., Lézine, A. M., Brewer, S., and Fouache, E.: Pollen- inferred Late-Glacial and Holocene climate in southern Balkans (lake Maliq), Quatern. Int., 200, 19-30, 2009.

Büntgen, U., Tegel W., and Nicolussi, K.: 2500 years of European climate variability and human susceptibility, Science, 331, 578582, 2011.

Čarni, A., Kostadinovski, M., and Matevski, V.: Species composition and syntaxonomic consideration of two communities of the Drabo-Cardaminion hirsutae in the southern part of the Republic of Macedonia, Acta Bot. Croat., 62, 47-56, 2003.

Caroli, I. and Caldara, M.: Vegetation history of Lago Battaglia (Eastern Gargano coast, Apulia Italy) during the middle-late Holocene, Veg. Hist. Archaeobot., 16, 317-327, 2007.

Combourieu-Nebout, N., Peyron, O., Bout-Roumazeilles, V., Goring, S., Dormoy, I., Joannin, S., Sadori, L., Siani, G., and Magny, M.: Holocene vegetation and climate changes in the central Mediterranean inferred from a high-resolution marine pollen record (Adriatic Sea), Clim. Past, 9, 2023-2042, https://doi.org/10.5194/cp-9-2023-2013, 2013.

de Beaulieu, J.-L., Brugiapaglia, E., Joannin, S., Guiter, F., Zanchetta, G., Wulf, S., Peyron, O., Bernardo, L., Didier, J., Stock, A., Rius, D., and Magny, M.: Late Glacial-Holocene abrupt vegetation changes at Lago Trifoglietti in Calabria, southern Italy: the setting of ecosystems in a refugial zone, Quaternary Sci. Rev., 158, 44-57, 2017.

Denéfle, M., Lézine, A.-M., Fouache, E., and Dufaure, J.-J.: A 12,000-Year Pollen Record from Lake Maliq, Albania, Quaternary Res., 54, 423-432, 2000.

Di Rita, F. and Magri, D.: Holocene drought, deforestation and evergreen vegetation development in the central Mediterranean: a 5500 year record from Lago Alimini Piccolo, Apulia, southeast Italy, Holocene, 19, 295-306, 2009. 
Eastwood, J. E.: East Mediterranean vegetation and climate change, in: Balkan Biodiversity Pattern and Process in the European Hotspot, edited by: Griffiths, H. I., Kryštufek, B., and Reed, J. M., Springer, 25-48, 2004.

Fægri, K. and Iversen, J.: Textbook of Pollen Analysis, 4th Edn., John Wiley \& Sons, Chichester, New York, Brisbane, Toronto, Singapore, 1989.

Florenzano, A., Marignani, M., Rosati, L., Fascetti, S., and Mercuri, A. M.: Are Cichorieae an indicator of open habitats and pastoralism in current and past vegetation studies?, Plant Biosyst., 149, 154-165, 2015.

Francke, A., Wagner, B., Leng, M. J., and Rethemeyer, J.: A Late Glacial to Holocene record of environmental change from Lake Dojran (Macedonia, Greece), Clim. Past, 9, 481-498, https://doi.org/10.5194/cp-9-481-2013, 2013a.

Francke, A., Wagner, B., Leng, M. J., and Rethemeyer, J.: Biogeochemical, sedimentological and isotopic sediment record of Lake Dojran, PANGAEA, https://doi.org/10.1594/PANGAEA,860791, 2013b.

Giesecke, T., Hickler, T., Kunkel, T., Sykes, M. T., and Bradshaw, R. H. W.: Towards an understanding of the Holocene distribution of Fagus sylvatica L., J. Biogeogr., 34, 118-131, 2007.

Gimbutas, M.: Anza, ca. 6500-5000 B.C.: A Cultural Yardstick for the Study of Neolithic Southeast Europe, J. Field Archaeol., 1, 27-66, 1974.

Giraudi, C., Magny, M., Zanchetta, G., and Drysdale, R. N.: The Holocene climatic evolution of Mediterranean Italy: A review of the continental geological data, Holocene, 21, 105-115, 2011.

Gogou, A., Triantaphyllou, M., Xoplaki, E., Izdebski, A., Parinos, C., Dimiza, M., Bouloubassi, I., Luterbacher, J., Kouli, K., Martrat, B., Toreti, A., Fleitmann, D., Rousakis, G., Kaberi, H., Athanasiou, M., and Lykousis, V.: Climate variability and socioenvironmental changes in the northern Aegean (NE Mediterranean) during the last 1500 years, Quaternary Sci. Rev., 136, 209-228, 2016.

Göktürk, O. M., Fleitmann, D., Badertscher, S., Cheng, H., Edwards, R. L., Leuenberger, M., Fankhauser, A., Tüysüz, O., and Kramers, J.: Climate on the southern Black Sea coast during the Holocene: implications from the Sofular Cave record, Quaternary Sci. Rev., 30, 2433-2445, 2011.

Griffiths, H. I., Reed, J. M., Leng, M. J., Ryana, S., and Petkovski, S.: The recent palaeoecology and conservation status of Balkan Lake Dojran, Biol. Conserv., 104, 35-49, 2002.

Grimm, E. C.: Tilia and Tilia-graph: pollen spreadsheet and graphics programs, 8th International Palynological Congress, Aix-enProvence, France, 6-12 September 1992, p. 56, 1992.

Harris, W. V.: Defining and detecting Mediterranean deforestation, $800 \mathrm{BCE}$ to $700 \mathrm{CE}$. The Ancient Mediterranean environment between science and history, Brill, 173-194, 2013.

Izdebski, A., Koloch, G., and Sloczynski, T.: Exploring Byzantine and Ottoman Economic History with the Use of Palynological Data: A Quantitative Approach, Jahrbuch der Osterreichischen Byzantinistik, 65, 67-109, 2015.

Jahns, S.: The Holocene history of vegetation and settlement at the coastal site of Lake Voulkaria in Acarnania, western Greece, Veg. Hist. Archaeobot., 14, 55-66, 2005.

Jahns, S. and van den Bogaard, C.: New palynological and tephrostratigraphical investigations of two salt lagoons on the island of
Mljet, south Dalmatia, Croatia, Veg. Hist. Archaeobot., 7, 219234, 1998.

Johnsen, S. J., Dahl-Jensen, D., Gundestrup, N., Steffensen, J. P., Clausen, H. B., Miller, H., Masson-Delmotte, V., Sveinbjörnsdottir, A. E., and White, J.: Oxygen isotope and palaeotemperature records from six Greenland ice-core stations: Camp Century, Dye-3, GRIP, GISP2, Renland and NorthGRIP, J. Quaternary Sci., 16, 299-307, 2001.

Kaiser, T. and Voytek, B.: Sedentism and Economic Change in the Balkan Neolithic, J. Anthropol. Archaeol., 2, 323-353, 1983.

Keukelaar, F., de Goffau, A., Pradhan, T., Sutmuller, G., Misurovic, A., Ivanovic, S., Uskokovic, B., Hetoja, A., Haxhimihali, E., rifti, A., Kapidani, E., Kashta, L., and Gulan, A.: Lake Shkoder Transboundary Diagnostics Analysis, Albania \& Montenegro, World Bank (IBRD), 178 pp., available at: http://www.gov.me/ files/1248091671.pdf (last access: March 2018), 2006.

Kokkinidou, D. and Trantalidou, K.: Neolithic and Bronze Age Settlement in Western Macedonia, Annu. Brit. Sch. Athens, 86, 93106, 1991.

Komárek, J. and Jankovská, V.: Review of the Green Algal Genus Pediastrum; Implication for Pollen-analytical Research, Bibliotheca Phycologica, 108, edited by: Kies, L. and Schnetter, R., Cramer, Berlin Stuttgart, 127 pp., 2001.

Kotthoff, U., Müller, U. C., Pross, J., Schmiedl, G., Lawson, I. T., van de Schootbrugge, B., and Schulz, H.: Late Glacial and Holocene vegetation dynamics in the Aegean region: an integrated view based on pollen data from marine and terrestrial archives, Holocene, 18, 1019-1032, 2008.

Kouli, K.: Plant landscape and land use at the Neolithic lake settlement of Dispilió (Macedonia, northern Greece), Plant Biosyst., 149, 195-204, 2015.

Kouli, K. and Dermitzakis, M. D.: Lake Orestiás (Kastoria, Northern Greece), Grana, 49, 154-156, 2010.

Lawson, I., Frogley, M., Bryant, C., Preece, R., and Tzedakis, P.: The Late Glacial and Holocene environmental history of the Ioannina basin, north-west Greece, Quaternary Sci. Rev., 23, 1599-1625, 2004.

Lézine, A. M., Von Grafenstein, U., Andersen, N., Belmecheri, S., Bordon, A., Caron, B., Cazet, J. P., Erlenkeuser, H., Fouache, E., Grenier, C., Huntsman-Mapila, P., Hureau-Mazaudier, D., Manelli, D., Mazaud, A., Robert, C. Sulpizio, R., Tiercelin, J. J., Zanchetta, G., and Zeqollari, Z.: Lake Ohrid, Albania, provides an exceptional multi-proxy record of environmental changes during the last glacial-interglacial cycle, Palaeogeogr. Palaeocl., 287, 116-127, 2010.

Litt, T., Krastel, S., Sturm, M., Kipfer, R., Örcen, S., Heumann, G., Franz, S. O., Ülgen, U. B., and Niessen, F.: "PALEOVAN", International Continental Scientific Drilling Program (ICDP): site survey results and perspectives, Quaternary Sci. Rev., 28, 15551567, 2009.

Litt, T., Ohlwein, C., Neumann, F. H., Hense, A., and Stein, M.: Holocene climate variability in the Levant from the Dead Sea pollen record, Quaternary Sci. Rev., 49, 95-105, 2012.

Magri, D. and Sadori, L.: Late Pleistocene and Holocene pollen stratigraphy at Lago di Vico, central Italy, Veg. Hist. Archaeobot., 8, 247-260, 1999.

Marignani, M., Chiarucci, A., Sadori, L., and Mercuri, A. M.: Natural and human impact in Mediterranean landscapes: An intrigu- 
ing puzzle or only a question of time?, Plant Biosyst., 151, 900905, 2017.

Marinova, E., Tonkov, S., Bozilova, E., and Vajsov, I.: Holocene anthropogenic landscapes in the Balkans: the palaeobotanical evidence from southwestern Bulgaria, Veget. Hist. Archaeobot., 21, 413-427, 2012.

Masi, A., Francke, A., Pepe, C., Thienemann, M., Wagner, B., and Sadori, L.: Pollen and biomarker record of Lake Dojran, PANGAEA, https://doi.org/10.1594/PANGAEA.885797, 2017.

Mazzini, I., Gliozzi, E., Galaty, M., Bejko, L., Sadori, L., SoulieMarsche, I., Koçi, R., Van Welden, A., and Bushati, S.: Holocene evolution of Lake Shkodra: Multidisciplinary evidence for diachronic landscape change in northern Albania, Quaternary Sci. Rev., 136, 85-95, 2016.

Melovski, L., Velevski, M., Matevski, V., Avukatov, V., and Sarov, A.: Using important plant areas and important bird areas to identify Key Biodiversity Areas in the Republic of Macedonia, J. Threat. Taxa, 4, 2766-2778, 2012.

Mercuri, A. M., Bandini Mazzanti, M., Torri, P., Vigliotti, L., Bosi, G., Florenzano, A., Olmi, L., and Massamba N'siala, I.: A marine/terrestrial integration for mid-late Holocene vegetation history and the development of the cultural landscape in the Po valley as a result of human impact and climate change, Veg. Hist. Archaeobot., 21, 353-372, 2012.

Mercuri, A. M., Bandini Mazzanti, M., Florenzano, A., Montecchi, M. C., and Rattighieri, E.: Olea, Juglans and Castanea: The OJC group as pollen evidence of the development of human-induced environments in the Italian peninsula, Quatern. Int., 303, 24-42, 2013a.

Mercuri, A. M., Mazzanti, M. B., Florenzano, A., Montecchi, M. C., Rattighieri, E., and Torri, P.: Anthropogenic Pollen Indicators (API) from archaeological sites as local evidence of humaninduced environments in the Italian peninsula, Annali di Botanica, 3, 143-153, 2013b.

Miebach, A., Niestrath, P., Roeser, P., and Litt, T.: Impacts of climate and humans on the vegetation in northwestern Turkey: palynological insights from Lake Iznik since the Last Glacial, Clim. Past, 12, 575-593, https://doi.org/10.5194/cp-12575-2016, 2016.

Milner, A. M., Collier, R. E. L., Roucoux, K. H., Muller, U. C., Pross, J., Kalaitzidis, S., Christanis, K., and Tzedakis, P. C.: Enhanced seasonality of precipitation in the Mediterranean during the early part of the Last Interglacial, Geology, 40, 919-922, 2012.

Morellon, M., Anselmetti, F. S., Ariztegui, D., Brushulli, B., Sinopoli, G., Wagner, B., Sadori, L., Gilli, A., and Pambuku, A.: Human-climate interactions in the central Mediterranean region during the last millennia: The laminated record of Lake Butrint (Albania), Quaternary Sci. Rev., 136, 134-152, 2016.

Müller, U. C., Pross, J., Tzedakis, P. C., Gamble, C., Kotthoff, U., Schmiedl, G., Wulf, S., and Christanis, K.: The role of climate in the spread of modern humans into Europe, Quaternary Sci. Rev., 30, 273-279, 2011.

Panagiotopoulos, K., Aufgebauer, A., Schäbitz, F., and Wagner, B.: Vegetation and climate history of the Lake Prespa region since the Late Glacial, Quatern. Int., 293, 157-169, 2013.

Panagiotopoulos, K., Böhm, A., Leng, M. J., Wagner, B., and Schäbitz, F.: Climate variability over the last $92 \mathrm{ka}$ in SW Balkans from analysis of sediments from Lake Prespa,
Clim. Past, 10, 643-660, https://doi.org/10.5194/cp-10-6432014, 2014.

Petkovski, S., Matevski, V., Melovski, L., Andonov, S., and Spirkovski, Z.: Capacity self-assessment within the thematic area of biodiversity, UNDP, Skopje, 2004.

Popovska, C., Bonacci, O., and Geshovska, V.: Climatic or Anthropogenic Impacts - Case Study Dojran Lake, International Journal of Environmental Engineering and Natural Resources, 1, 140149, 2014.

Pollegioni, P., Woeste, K., Chiocchini, F., Del Lungo, S., Ciolfi, M., Olimpieri, I., Tortolano, V., Clark, J., Hemery, G. E., Mapelli, S., and Malvolti, M. E.: Rethinking the history of common walnut (Juglans regia L.) in Europe: Its origins and human interactions, PLoS ONE, 12, e0172541, https://doi.org/10.1371/journal.pone.0172541, 2017.

Pross, J., Kotthoff, U., Müller, U. C., Peyron, O., Dormoy, I., Schmiedl, G., Klaitzidis, S., and Smith, A. M.: Massive perturbation in terrestrial ecosystems of the Eastern Mediterranean region associated with the $8.2 \mathrm{kyr}$ BP climatic event, Geology, 37, 887890, 2009.

Pross, J., Koutsodendris, A., Christanis, K., Fischer, T., Fletcher, W. J., Hardiman, M., Kalaitzidis, S., Knipping, M., Kotthoff, U., Milner, A. M., Müller, U. C., Schmiedl, G., Siavalas, G., Tzedakis, P. C., and Wulf, S.: The 1.35-Ma-long terrestrial climate archive of Tenaghi Philippon, northeastern Greece: Evolution, exploration, and perspectives for future research, Newsl. Stratigr., 48, 253-276, 2015.

Reille, M.: Pollen et spores d'Europe et d'Afrique du Nord, Laboratoire de Botanique Historique et Palynologie, Université d'Aix Marseille III, Marseille, 1992.

Reille, M.: Pollen et spores d'Europe et d'Afrique du Nord - Suppément 1, Laboratoire de Botanique Historique et Palynologie, Université d'Aix Marseille III, Marseille, 1995.

Reille, M.: Pollen et spores d'Europe et d'Afrique du Nord - Supplément 2, Laboratoire de Botanique Historique et Palynologie, Université d'Aix Marseille III, Marseille, 1998.

Roucoux, K. H., Tzedakis, P. C., Lawson, I. T., and Margari, V.: Vegetation history of the penultimate glacial period (Marine Isotope Stage 6) at Ioannina, north-west Greece, J. Quaternary Sci., 26, 616-626, 2011.

Sadori, L. and Narcisi, B.: The postglacial record of environmental history from Lago di Pergusa (Sicily), Holocene, 11, 655-671, 2001.

Sadori, L., Giraudi, C., Petitti, P., and Ramrath, A.: Human impact at Lago di Mezzano (central Italy) during the Bronze Age: A multidisciplinary approach, Quatern. Int., 113, 5-17, 2004.

Sadori, L., Zanchetta, G., and Giardini, M.: Last Glacial to Holocene palaeoenvironmental evolution at Lago di Pergusa (Sicily, Southern Italy) as inferred by pollen, microcharcoal, and stable isotopes, Quatern. Int., 181, 4-14, 2008.

Sadori, L., Ortu, E., Peyron, O., Zanchetta, G., Vannière, B., Desmet, M., and Magny, M.: The last 7 millennia of vegetation and climate changes at Lago di Pergusa (central Sicily, Italy), Clim. Past, 9, 1969-1984, https://doi.org/10.5194/cp-91969-2013, 2013.

Sadori, L., Giardini, M., Gliozzi, E., Mazzini, I., Sulpizio, R., van Welden, A., and Zanchetta, G.: Vegetation, climate and environmental history of the last 4500 years at lake Shkodra (Albania/Montenegro), Holocene, 25, 435-444, 2015a. 
Sadori, L., Masi, A., and Ricotta, C.: Climate driven past fires in central Sicily, Plant Biosyst., 149, 166-173, 2015 b.

Sadori, L., Giraudi, C., Masi, A., Magny, M., Ortu, E., Zanchetta, G., and Izdebski, A.: Climate, environment and society in southern Italy during the last 2000 years. A review of the environmental, historical and archaeological evidence, Quaternary Sci. Rev., 136, 173-188, 2016a.

Sadori, L., Koutsodendris, A., Panagiotopoulos, K., Masi, A., Bertini, A., Combourieu-Nebout, N., Francke, A., Kouli, K., Joannin, S., Mercuri, A. M., Peyron, O., Torri, P., Wagner, B., Zanchetta, G., Sinopoli, G., and Donders, T. H.: Pollenbased paleoenvironmental and paleoclimatic change at Lake Ohrid (south-eastern Europe) during the past $500 \mathrm{ka}$, Biogeosciences, 13, 1423-1437, https://doi.org/10.5194/bg-13-14232016, 2016 b.

Smit, A.: A scanning electron microscopical study of the pollen morphology in the genus Quercus, Acta Bot. Neerl., 22, 655665, 1973.

Sotiria, K. and Petkovski, S.: Lake Doiran - An overview of the current situation, Greek Biotope/ Wetland Centre (EKBY), Society for the Investigation and Conservation of Biodiversity and the Sustainable Development of Natural Ecosystems (BIOECO), Thermi, Greece, 2004.

Staubwasser, M. and Weiss, H.: Holocene climate and cultural evolution in late prehistoric-early historic West Asia, Quaternary Res., 66, 372-387, 2006.

Stockmarr, J.: Tables with spores used in absolute pollen analysis, Pollen and Spores, 13, 614-621, 1971.

Thienemann, M., Masi, A., Kusch, S., Sadori, L., John, S., Francke, A., Wagner, B., and Rethemeyer, J.: Reconstructing environmental and human settlement history on the southern Balkan Peninsula using lipid biomarker, pollen, and microcharcoal data from Lake Dojran sediments, Holocene, 27, 1103-1114, 2017.

Tinner, W., van Leeuwen, J. F. N., Colombaroli, D., Vescovi, E., van der Knaap, W. O., Henne, P. D., Pasta, S., D’Angelo, S., and La Mantia, T.: Holocene environmental and climatic changes at Gorgo Basso, a coastal lake in southern Sicily, Italy, Quaternary Sci. Rev., 28, 1498-1510, 2009.

Tonkov, S. and Marinova, E.: Pollen and plant macrofossil analyses of mid-Holocene radiocarbon dated profiles from two subalpine lakes in Rila Mountains, Bulgaria, Holocene, 15, 663-671, 2005.

Tonkov, S., Panovska, H., Possnert, G., and Bozilova, E.: The Holocene vegetation history of Northern Pirin Mountain, southwestern Bulgaria: pollen analysis and radiocarbon dating of a core from Lake Ribno Ban derishko, Holocene, 12, 201-210, 2002.

Tonkov, S., Bozilova, E., Possnert, G., and Velčev, A.: A contribution to the postglacial vegetation history of the Rila Mountains, Bulgaria: The pollen record of Lake Trilistnika, Quatern. Int., 190, 58-70, 2008.

Tonkov, S., Bozilova, E., and Possnert, G.: Late Glacial to Holocene vegetation development in the Central Rila Mountains, Bulgaria, Holocene, 26, 17-28, 2016.

Tonkov, S., Possnert, G., Bozilova, E., Marinova, E., and Pavlova, D.: On the Holocene vegetation history of the Central Rila Mountains, Bulgaria: The palaeoecological record of peat bog Vodniza (2113 m), Rev. Palaeobot. Palyno., 250, 16-26, 2018.
Tzedakis, P. C.: Vegetation change through glacial/interglacial cycles: a long pollen sequence perspective, Philos. T. Roy. Soc. B, 345, 403-432, 1994.

Tzedakis, P. C.: Seven ambiguities in the Mediterranean palaeoenvironmental narrative, Quaternary Sci. Rev., 26, 2042-2066, 2007.

Tzedakis, P. C., Hooghiemstra, H., and Pälike, H.: The last 1.35 million years at Tenaghi Philippon: revised chronostratigraphy and long-term vegetation trends, Quaternary Sci. Rev., 25, 34163430, 2006.

Valsecchi, V., Finsinger, W., Tinner, V., and Ammann, B.: Testing the influence of climate, human impact and fire on the Holocene population expansion of Fagus sylvatica in the southern Prealps (Italy), Holocene, 18, 603-614, 2008.

Vanniére, B., Power, M. J., Roberts, N., Tinner, W., Carrión, J., Magny, M., Bartlein, P., Colombaroli, D., Daniau, A. L., Finsinger, W., Gil-Romera, G., Kaltenrieder, P., Pini, R., Sadori, L., Turner, R., Valsecchi, V., and Vescovi, E.: CircumMediterranean fire activity and climate changes during the mid-Holocene environmental transition (8500-2500 cal. BP), Holocene, 21, 53-73, 2011.

van Zeist, W., Woldring, H., and Stapert, D.: Late Quaternary vegetation and climate of southwestern Turkey, Palaeohistoria, 17, 55-143, 1975.

Wagner, B., Lotter, A. F., Nowaczyk, N., Reed, J. M., Schwalb, A., Sulpizio, R., Valsecchi, V., Wessels, M., and Zanchetta, G.: A 40,000-year record of environmental change from ancient Lake Ohrid (Albania and Macedonia), J. Paleolimnol., 41, 407-430, 2009.

Wagner, B., Wilke, T., Francke, A., Albrecht, C., Baumgarten, H., Bertini, A., Combourieu-Nebout, N., Cvetkoska, A., D’Addabbo, M., Donders, T. H., Föller, K., Giaccio, B., Grazhdani, A., Hauffe, T., Holtvoeth, J., Joannin, S., Jovanovska, E., Just, J., Kouli, K., Koutsodendris, A., Krastel, S., Lacey, J. H., Leicher, N., Leng, M. J., Levkov, Z., Lindhorst, K., Masi, A., Mercuri, A. M., Nomade, S., Nowaczyk, N., Panagiotopoulos, K., Peyron, O., Reed, J. M., Regattieri, E., Sadori, L., Sagnotti, L., Stelbrink, B., Sulpizio, R., Tofilovska, S., Torri, P., Vogel, H., Wagner, T., Wagner-Cremer, F., Wolff, G. A., Wonik, T., Zanchetta, G., and Zhang, X. S.: The environmental and evolutionary history of Lake Ohrid (FYROM/Albania): interim results from the SCOPSCO deep drilling project, Biogeosciences, 14, 2033-2054, https://doi.org/10.5194/bg-14-2033-2017, 2017.

Willis, K. J.: The vegetational history of the Balkans, Quaternary Sci. Rev., 13, 769-788, 1994.

Whitlock, C., Higuera, P. E., McWethy, D. B., and Briles, C. E.: Paleoecological Perspectives on Fire Ecology: Revisiting the FireRegime Concept, Open Ecol. J., 3, 6-23, 2010.

Woldring, H. and Bottema, S.: The vegetation history of EastCentral Anatolia in relation to archaeology: the Eski Acıgöl pollen evidence compared with the Near Eastern environment, Palaeohistoria, 43/44, 1-34, 2003.

Xoplaki, E., Fleitmann, D., Luterbacher, J., Wagner, S., Haldon, J. F., Zorita, E., Telelis, I., Toreti, A., and Izdebski, A.: The Medieval Climate Anomaly and Byzantium: A review of the evidence on climatic fluctuations, economic performance and societal change, Quaternary Sci. Rev., 136, 229-252, 2016.

Zanchetta, G., Van Welden, A., Baneschi, I., Drysdale, R., Sadori, L., Roberts, N., Giardini, M., Beck, C., Pascucci, V., and Sulpizio, R.: Multiproxy record for the last 4500 years from Lake 
Shkodra (Albania/Montenegro), J. Quaternary Sci., 27, 780-789, 2012.

Zanchetta, G., Regattieri, E., Isola, I., Drysdale, R. N., Bini, M., Baneschi, I., and Hellstrom, J. C.: The so-called "4.2 event" in the central mediterranean and its climatic teleconnections, Alpine and Mediterranean Quaternary, 29, 5-17, 2016.
Zhang, X., Reed, J., Wagner, B., Francke, A., and Levkov, Z.: Late Glacial and Holocene climate and environmental change in the northeastern Mediterranean region: diatom evidence from Lake Dojran (Republic of Macedonia/Greece), Quaternary Sci. Rev., 103, 51-66, 2014 